\title{
Jasna Góra \\ w pierwszych dniach września 1939 r. - fakty i legendy
}

\author{
Jasna Gora in the first days of September 1939. \\ Facts and legends
}

\begin{abstract}
The article discusses the issue of the so-called 'Jasna Gora lie', which appeared on 2 September 1939 in the Polish and world media. The initiators of this undertaking were well aware of the importance of Jasna Góra and the miraculous image of Our Lady of Czestochowa in Poland, as well as of the role it played in the process of cementing national consciousness. The relayed message conveyed false information that the Germans had demolished the sanctuary and profaned the miraculous icon.

News quickly leaked out to the international public opinion. The news from Czestochowa was featured in French, Belgian, Swedish, Italian and American newspapers on the front pages. The Germans reacted very quickly to the outbreak of world outrage. This matter was personally supervised by Joseph Goebbels, Minister of Propaganda of the Third Reich. As a matter of urgency, on 4 September he sent to Czestochowa the famous American journalist Ludwig 'Louis' Paul Lochner, who was to testify that the monastery of Jasna Gora was undamaged and that the miraculous icon was still available to the faithful. At the same time, Goebbels' propaganda showed the Germans as a noble and civilized nation that took holy places under their special care. Most historians believe that the provocation was prepared by the Germans themselves. The author of the article proposes a hypothesis that the Polish authorities could have been behind the Częstochowa rumor. Perhaps the tragic news from Czestochowa was supposed to raise the morale of the society, especially Polish soldiers. In the early days of the war there was yet another, half-legendary event. It was related to the attempt to destroy the monastery and the city by the German air force. For this purpose, three squadrons of combat aircraft took off on 1 September from the Pawelwitz Airport (today's Pawlowice, part of Wroclaw), heading for Częstochowa. None of them ever reached the target. From the
\end{abstract}


beginning of the war, there was a related social message about the 'miraculous defence of Czestochowa'.

The presented events caused the fact that in the early days of World War II Jasna Gora was at the centre of interest of almost the whole world. Afterwards, the Germans were very careful to retain the image of the monastery as a normally functioning sanctuary. It was mainly owing to this incident that Jasna Góra managed to go through the period of occupation with relatively little losses.

Keywords: Jasna Gora, Czestochowa, the Jasna Góra lie, 1939, Ludwig 'Louis' Paul Lochner

\section{1.}

Wokół każdego miejsca świętego zawsze krąży mnóstwo opowieści. W większości przypadków opierają się one na dziejącej się faktycznie historii sanktuarium. Jednak im większa ranga religijna i narodowa danego miejsca, tym większy jest zakres opowieści legendarnych, niepopartych żadnymi faktami, lub dowolnie te fakty interpretujących. Większość takich mitycznych przekazów nawiązuje do funkcji religijnej ośrodka. Zawsze jednak obok tego nurtu obecne były wieści, wskazujące na polityczną, a może raczej polityczno-narodową rolę miejsca świętego. Często wiązało się to z cudowną interwencją obiektu kultu w obronie sanktuarium, a szerzej również w bitwach z poganami. Podobne zjawisko obserwujemy w przypadku Jasnej Góry.

Prowadząc przez szereg lat studia związane z Jasną Górą jako światowym centrum pielgrzymkowym, zafrapował mnie krótki epizod jej dziejów, który do chwili obecnej nie jest dostatecznie wyjaśniony. Choć opiera się na konkretnych faktach, wiążą się z nim również pewne wydarzenia, które w rzeczywistości nigdy nie zaistniały. Wiele miało charakter przekazów legendarnych. Epizod ten wiąże się z najnowszą historią klasztoru jasnogórskiego. Konkretnie chodzi o pojawienie się w dniu 2 września 1939 r. w mediach polskich i światowych nieprawdziwej informacji, jakoby Niemcy zburzyli Jasną Górę oraz sprofanowali sanktuarium i cudowny obraz Matki Bożej Częstochowskiej. Pojawienie się takiej wiadomości potwierdzają historycy, uwage poświęcały jej również liczne tytuły prasowe z początków września 1939 r. Od kilkudziesięciu lat trwa dyskusja dotycząca źródła tych informacji. Większość historyków skłonna jest przyjąć, że pomysł i wykonanie takiej akcji propagandowej wiąże się ze stroną niemiecką. Spoglądając jednak na ten incydent $z$ naszej perspektywy, może się nasunąć 
pytanie, czy przypisywanie tego wyłącznie Niemcom jest uzasadnione i rzeczywiście tak jednoznaczne? Niejako na poboczu podejmowanych prób wyjaśnienia tego, co działo się na początku września 1939 r., pozostaje historia lotów bombowców niemieckich w dniach 1-2 września, które miały dokonać zniszczenia klasztoru i miasta. Mimo że obszerniejsze informacje na ten temat pokazały się dopiero w latach 80. XX w., od początków wojny funkcjonował przekaz społeczny o „cudownej obronie Częstochowy”. Analizując wszystkie materiały, można stwierdzić, że wszystkie te wydarzenia wiązały się ze sobą. Wydaje się, że cała ta rzecz jest warta przypomnienia.

\section{2.}

W przededniu II wojny światowej, podobnie jak w całej Polsce, również w Częstochowie i na Jasnej Górze odczuwano coraz większe zagrożenie ze strony niemieckiej. Uczucie to potęgowało się niemal z każdym dniem. Wszyscy zdawali sobie sprawę, że ze względu na niekorzystne usytuowanie miasta w stosunku do granicy polsko-niemieckiej (około $30 \mathrm{~km}$ ) w momencie wybuchu wojny Częstochowa stanie się jednym z pierwszych obiektów ataku wroga. W dniu 30 sierpnia powstała w mieście Straż Obywatelska mająca pilnować porządku, organizować gaszenie pożarów, opiekę nad rannymi, grzebanie zabitych. Ruszyły prace związane z kopaniem rowów przeciwczołgowych i schronów przeciwlotniczych. Ludność została zaopatrzona w maski przeciwgazowe. Wieczorami miasto tonęło w ciemnościach, ponieważ obowiązywało zarządzenie o zaciemnieniu. Okna mieszkań zabezpieczano przed bombardowaniem, naklejając specjalne taśmy papierowe. Mieszkańcy robili zapasy żywności i środków opatrunkowych, wielu z nich wyjechało. Były to przede wszystkim kobiety i dzieci oraz osoby starsze. Kierowali się na Kielce, Warszawę i Lublin. Dopiero 31 sierpnia - po wielu dniach wyczekiwania - ogłoszono powszechną mobilizację. Do obrony miasta wyznaczono 7 Dywizję Piechoty, którą dowodził gen. bryg. Janusz Gąsiorowski. Zajmowała stanowisko na przedpolu Częstochowy, na styku Armii „Kraków” i „Łódź”. Wspierać ją miały m.in. Krakowska Brygada Kawalerii (dowódca gen. bryg. Zygmunt Piasecki) oraz Wołyńska Brygada Kawalerii, która stacjonowała we wsi Mokra (Pietrzykowski 1985). Obszar wokół miasta był przygotowany do obrony. Do września 1939 r. wybudowano 19 nowoczesnych schronów bojowych i obserwacyjnych, a dalsze 4 ulokowano w pobliskim Lublińcu. Ponadto 
przygotowano schrony tradycyjne (drewniano-ziemne), pola z zaporami czołgowymi, rowami przeciwpancernymi, okopami itp. Pozycje bojowe dywizja obsadziła 29 sierpnia.

Mimo rosnącego napięcia Jasna Góra starała się funkcjonować normalnie. W klasztorze przebywało w tym czasie 16 ojców - kapłanów oraz 15 braci. Od 1931 r. generałem zakonu był ojciec Pius Przeździecki (1865-1942). W dniu 15 sierpnia wyjechał na Węgry w celu wizytacji tamtejszej prowincji paulińskiej. Tam rozchorował się i na Jasną Górę powrócił dopiero 8 czerwca 1940 r. Od 1934 r. funkcje przeora klasztoru jasnogórskiego pełnił ojciec Norbert Motylewski (1885-1943) (ryc. 1),

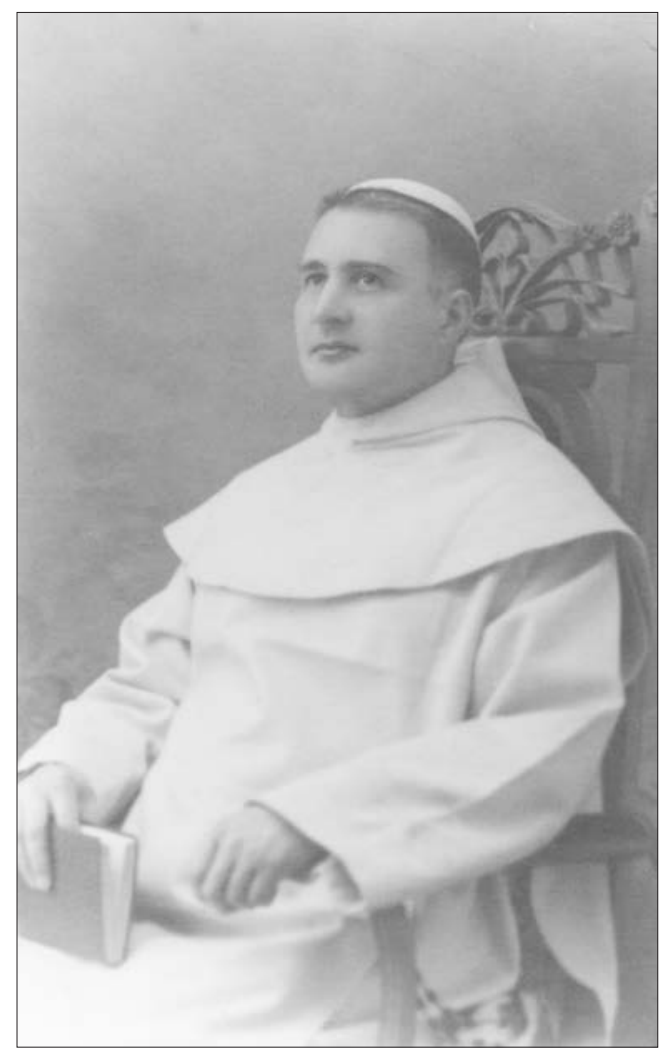

Ryc. 1. Ojciec Norbert Motylewski (1885-1943), przeor Jasnej Góry w latach 1934-1943 (NAC sygn. 1-R-616) na barki którego spadło przygotowanie Jasnej Góry na nadchodzące ciężkie dni.

Narastające zagrożenie wojenne nie powstrzymało pielgrzymowania na Jasną Górę, choć nie było ono tak liczne, jak w poprzednich latach. Do dnia 1 września notowano ponad 700 tys. pątników (w 1938 r. frekwencja wyniosła około 1,2 mln osób; Jackowski 2005). Główne uroczystości religijne - 3 maja, 15 i 26 sierpnia - stały się też wielkimi zoromadzeniami patriotycznymi. Podobny charakter miały inne wydarzenia, a zwłaszcza Dni Morza (maj) czy Kongres Tercjarzy (lipiec). W pielgrzymce tercjarzy uczestniczyło około 120 tys. osób. Przewodził im generał Józef Haller, który wygłosił płomienne przemówienie, pełne treści patriotycznych.

W sierpniu dotarły już do Polski informacje, że Adolf Hitler zamierza rozpocząć najazd na nasz kraj 
w dniach 24-26 sierpnia. Świadomość ta rzutowała na przebieg święta Matki Bożej Częstochowskiej w dniu 26 sierpnia. Mimo panującej atmosfery wojennej na Jasną Górę przybyło około 100 tys. pielgrzymów, wśród których wyróżniały się liczne osoby w mundurach wojskowych. Oczywiście liczba pątników była mniejsza niż w latach poprzednich. Ze względu na brak chętnych musiano np. odwołać 60 zaplanowanych wcześniej dodatkowych pociągów. Podczas uroczystości przemawiali m.in. ojciec Alfons Jędrzejewski, biskup częstochowski Teodor Kubina oraz kapitan Władysław Polesiński, twórca organizacji Zakon Krzyża i Miecza. Wszystkie wystąpienia były pełne elementów patriotycznych. W pewnym momencie do mikrofonu podszedł przeor ojciec Norbert Motylewski. Przerwał przemówienia, informując wiernych, iż z kręgów wojskowych dostał wiadomość, że wybuch wojny jest kwestia godzin. Zalecił wiernym jak najszybszy powrót do domów. Wśród płaczu wielu zebranych odśpiewano Boże coś Polskę i zakończono nabożeństwo. Nie wiedziano jeszcze, że Hitler przesunął termin napaści na nasz kraj z 26 sierpnia na 1 września (Zbudniewek 1981, 1991).

Klasztor jasnogórski złożył ofiarę na dozbrojenie armii polskiej, przekazując na ten cel część biżuterii. Nie zapominał też o przygotowaniach na wypadek wojny. Główną uwagę paulini zwracali na zabezpieczenie całego terenu przed spodziewanymi pożarami. W tym celu w wielu miejscach gromadzono piasek i zapasy wody. Wprowadzono system stałych straży nocnych. Zakonnicy zabezpieczyli skarbiec i obiekty zabytkowe, gromadzili żywność, artykuły medyczne i przemysłowe. Część ważniejszych obiektów ze skarbca jasnogórskiego przewieziono do klasztorów w Leśniowie i w Leśnej Podlaskiej. Codziennie przed cudownym obrazem Matki Bożej odprawiano modły o oddalenie od Polski grożącego jej niebezpieczeństwa. Począwszy od 26 sierpnia, przed szczytem odbywała się wieczorami nowenna w intencji Ojczyzny. Ostatnie takie nabożeństwo miało miejsce 31 sierpnia. Prowadził je ojciec Polikarp Stefan Sawicki, świetny kaznodzieja i wielki patriota. (Pietrzykowski 1987, Zbudniewek 1981).

W piątek 1 września między godzinami 5 a 6 rano mieszkańców Częstochowy obudziła silna kanonada artyleryjska. Rozpoczęła się wojna! (ryc. 2). Mimo czterokrotnej przewagi nacierających wojsk niemieckich (trzy dywizje piechoty i jedna dywizja pancerna) polscy żołnierze dzielnie bronili powierzonego im 


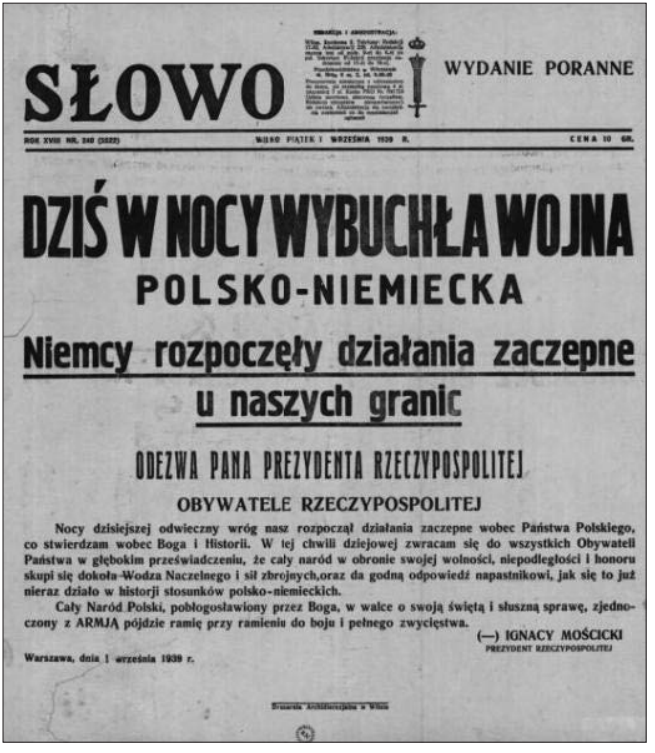

Ryc. 2. Strona tytułowa pisma „Słowo” 1939, nr 240 odcinka frontu. Niebawem nadleciały nad miasto pierwsze samoloty niemieckie. Zrzuciły kilka bomb, z których kilka nie wybuchło. Lekceważąc niebezpieczeństwo, mieszkańcy nie chronili się w schronach, natomiast $z$ zainteresowaniem obserwowali przelatujące maszyny. Pod wieczór 1 września oddziały 7 Dywizji Piechoty wycofały się z wyznaczonej linii obrony pod Częstochowę. Sytuacja na froncie sprawiła więc, że w dniu 2 września walki toczyły się $\mathrm{w}$ nieodległym sąsiedztwie miasta, które znalazło się w bezpośrednim zasięgu niemieckiej artylerii. Zaczęło pojawiać się coraz więcej samolotów wroga. Zrzucane bomby powodowały

straty osobowe i materialne. W nocy z 2 na 3 września, po kolejnym dniu ciężkich walk, bojąc się okrążenia przez Niemców z drugiej strony miasta, wycofano dywizję w kierunku na Janów. Ostatnie pododdziały, po wysadzeniu mostów na Warcie, opuściły miasto 3 września nad ranem. Wycofująca się dywizja została niebawem niemal zupełnie rozbita pod Janowem i Lelowem, a gen. J. Gąsiorowski dostał się do niewoli. Częstochowy nie uratowały też spektakularne sukcesy Wołyńskiej Brygady Kawalerii pod Mokrą, Krakowskiej Brygady Kawalerii czy Strzelców Poleskich 30. Pułku Piechoty. Po dwóch dniach bohaterskich walk Polaków linia obrony „reduty częstochowskiej” przestała istnieć, co umożliwiło Niemcom wkroczenie do miasta i dalszy marsz w kierunku Warszawy (Grządzielski 2006, Pietrzykowski 1985, Zbudniewek 1981).

W pierwszym dniu wojny przez miasto przechodziły tysiące uchodźców, do których przyłączali się mieszkańcy miasta. Wyróżniały się dwie wyraźne grupy uczestników tego exodusu: 1. mężczyźni, którzy wobec zbyt późno ogłoszonej mobilizacji nie dotarli do wojska, oraz ochotnicy (studenci, maturzyści, licealiści) pragnący wstąpić do armii; 2. mieszkańcy Częstochowy (Pietrzykowski 1985: 
17). Miasto opuściły władze, ewakuowane zostały urzędy, wywędrowali nawet funkcjonariusze policji oraz strażacy. Ci ostatni zabrali ze sobą m.in. wozy przeciwpożarowe (Pietrzykowski 1987).

W niedzielę 3 września około godziny 5 nad ranem do Częstochowy wkroczyli Niemcy. Miasto sprawiało wrażenie wyludnionego, bowiem ludność zamknęła się w swych domach. Nikt nie wychodził na ulice. Ojciec P. S. Sawicki w swym pamiętniku zanotował pod tą datą:

„Wstaję o 3.00. Cisza... Mgła gęsta... Idę na szczyt. Tak. Jesteśmy w mocy wroga. Modlę się o cud b. b. gorąco. Na świtaniu słyszę przeplatany płaczem śpiew babinki na dole przed szczytem. Cicho... jakaś ta cisza złowroga. Odeszli. Odeszli ci, co tak zapewniali, że po trupach ich wejdzie wróg do Częstochowy. Zostaliśmy sami. Został biedny lud. Została z nami Matka. Został z nami Bóg" (cyt. za: Pietrzykowski 1987: 123).

Około 7 rano na dziedziniec klasztorny wjechali niemieccy motocykliści. W południe przeor N. Motylewski otrzymał polecenie natychmiastowego stawienia się w ratuszu u niemieckiego komendanta miasta płk. Oscara Döppinga. Gdy przybył do urzędu, młody adiutant Döppinga, ujrzawszy zakonnika, zrzucił go ze schodów. Z pomocą obecnych tam Polaków przeor pozbierał się i wszedł do gabinetu komendanta. Usłyszał wtedy krzykliwe pytanie o cudowny obraz. Niemca interesował przede wszystkim stan obrazu, pytał też, czy Matka Boża nadal posiada słynne korony. Krzyczał, że paulini muszą się podporządkować zarządzeniom władz, a w przypadku nieposłuszeństwa zostaną powieszeni. Nakazał też zakonnikom modlić się za pomyślność Niemiec. Przeor spokojnie odpowiedział, że obraz nieustająco znajduje się w kaplicy i jest w dobrym stanie. Po powrocie do klasztoru zaniepokojeni pytaniami Niemca paulini postanowili jednak ukryć oryginał obrazu. Został on zamurowany w jednej z klasztornych ścian, a w raz z nim ukryto znajdujące się w skarbcu najcenniejsze eksponaty historyczne. W skrytce tej był przechowywany około 6 miesięcy, potem został ukryty w Starej Bibliotece. W miejsce cudownego obrazu wstawiono w kaplicy jego świetną kopię, wykonaną przez ojca Augustyna Jędrzejczyka. Przybyli po południu Niemcy uczestniczyli o godz. 16 w uroczystym odsłonięciu już nie obrazu, ale jego repliki.

Od pierwszego dnia po zajęciu miasta okupanci zaczęli licznie odwiedzać Jasną Górę. Początkowo ich buta i pogarda dla wszystkiego przejawiała się m.in. w tym, że do kościoła wchodzili w czapkach, często mając w ustach cygara czy papierosy. Był też przypadek, gdy Niemiec wszedł z psem, który miał nałożony na łeb różaniec. Stopniowo zaczęli zajmować coraz więcej pomieszczeń klasztornych. 
Na Jasnej Górze kwaterował garnizon wojska, zabytkowy arsenał przeznaczono na skład amunicji. Zajęto też tzw. „pokoje królewskie” oraz hotel „pątników”. Mimo tej wrogiej postawy sanktuarium jasnogórskie pozostawiono w spokoju. Przypadające w dniu 8 września święto Narodzenia Matki Bożej odprawiano $w$ tradycyjnym porządku. Jedynie liczba wiernych była znacznie mniejsza niż w poprzednich latach. Taka niecodzienna postawa okupantów i ich wielkie zainteresowanie cudownym obrazem wynikało przede wszystkim z pewnych wydarzeń medialnych, które działy się od drugiego dnia wojny (Pietrzykowski 1987, Zbudniewek 1981, 1991). Będzie o tym mowa w dalszej części rozważań.

\section{4.}

O ile stosunek Niemców do Jasnej Góry nie był jeszcze dokładnie sprecyzowany, o tyle od pierwszego dnia okupacji bardzo brutalnie potraktowali oni mieszkańców Częstochowy. Rozstrzeliwania i aresztowania miały już miejsce w dniu wkroczenia wojsk niemieckich. Masowo aresztowanych Polaków umieszczano - wobec braku pomieszczeń - m.in. w kościele pw. św. Zygmunta i w katedrze. Wczesnym popołudniem 4 września w kilku punktach rozległy się wystrzały. Przypuszcza się, że spowodowali je najpewniej niedoświadczeni niemieccy rekruci (Pietrzykowski 1985, 1987). Natychmiast rozpoczęły się represje wroga. Z domów wyciągano mieszkańców (w sumie około 10 tys. osób), których gromadzono na wielkich placach, m.in. przed katedrą, kościołem pw. św. Zygmunta i przed ratuszem. Zatrzymani leżeli twarzami do ziemi. Miejsca koncentracji aresztowanych otoczyli żołnierze z ciężką bronią maszynową. Zgromadzeni byli bici i szykanowani (ryc. 3-4). Wielu zatrzymanych rozstrzeliwano natychmiast, a za groby służyły wykopane w sierpniu rowy obronne. Więźniom zgromadzonym na placu katedralnym nakazano wejść do świątyni. Gdy zaczęli wykonywać to polecenie, żołnierze rozpoczęli do nich strzelać. Było wielu zabitych. Jeszcze w nocy Niemcy wchodzili do katedry, strzelając z broni krótkiej do stłoczonych tam więźniów. Osoby, które przeżyły, odzyskały wolność następnego dnia. Najdłużej (do 6 tygodni) przetrzymywano 80 więźniów-zakładników zamkniętych w koszarach 27 pułku piechoty. Według różnych źródeł zginęło wówczas od około 230 do 500 osób (Dubicki, Majzner 2006, Pietrzykowski 1985, Zbudniewek 1991). Ekshumacji dokonano w lutym 1940 r., niestety nie wszystkie ofiary zostały odnalezione bądź zidentyfikowane. Zamienione $\mathrm{w}$ więzienia świątynie zostały sprofanowane, jako 


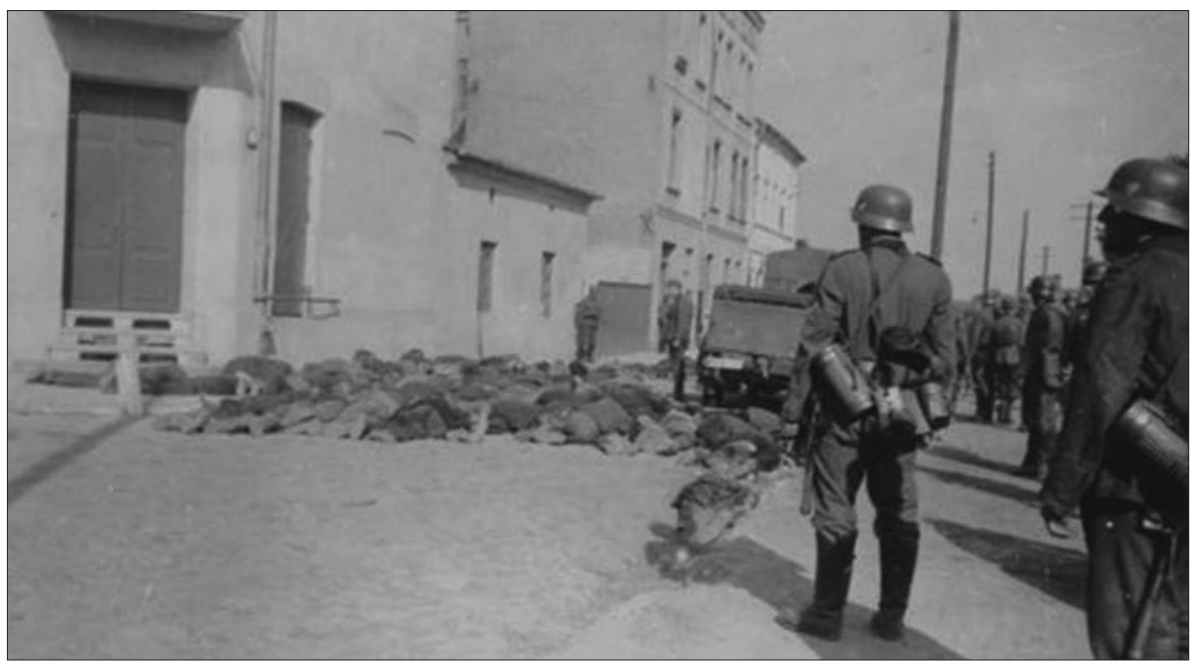

Ryc. 3. Częstochowa, 4 września 1939 r. - czarny poniedziałek (http://prawy.pl/1685-4 wrzesnia-1939-r-krwawy-poniedziałek-w-czestochowie/ (dostęp: 25. 06. 2016)

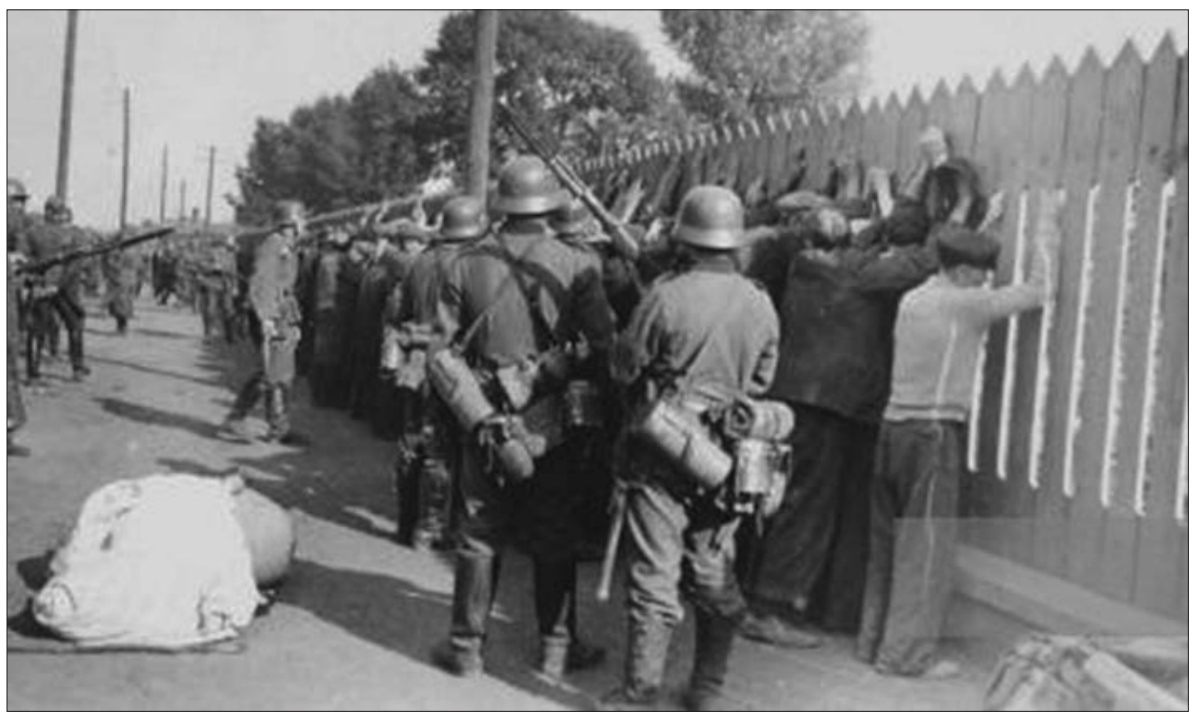

Ryc. 4. Częstochowa, 4 września 1939 r. - czarny poniedziałek (https://www.google. pl/imgres?imgurl=https $\% 3 \mathrm{~A} \% 2 \mathrm{E} \%$ Ewww.evangelici.info $\% 2 \mathrm{Ffiles} \% 2 \mathrm{Fu} 1 \% 2 \mathrm{Fghetto}$. jpg\&imgrefurl-h (dostęp: 25. 06. 2016) 
że przetrzymywane w nich osoby załatwiały tam swoje potrzeby fizjologiczne. W historii Częstochowy dzień ten nosi nazwę czarnego poniedziałku. Była to jedna z najcięższych zbrodni popełnionych przez żołnierzy Wehrmachtu podczas kampanii wrześniowej. Bolesław Kurkowski, sekretarz Straży Obywatelskiej, tak wspominał te wydarzenia:

„W poniedziałek 4 września 1939 roku zdawało się, że nad Częstochową otwarło się piekło. Żołnierze niemieccy siłą wyciągali ludzi z domów i mieszkań, odrywali od rodzin, przy tym bili nieszczęsnych do nieprzytomności i po wyciągnięciu na ulicę lub podwórze rozstrzeliwali. Była to istna orgia niemieckiego żołdactwa, trudna do opisania w swej ohydzie i bezeceństwie" (cyt. za Pietrzykowski 1987: 126).

W święto Narodzenia Matki Bożej 8 września Niemcy zajęli dom Zgromadzenia Braci Szkół Chrześcijańskich przy ul. Pułaskiego 71/83. Odnaleziono m.in. fragmenty umundurowania polskich żołnierzy, którzy stacjonowali tam pod koniec sierpnia i w pierwszych dniach wojny. Zaaresztowano wszystkie znajdujące się w domu osoby, zarówno Braci Szkolnych, jak też osoby świeckie. W tym samym dniu zostały one rozstrzelane. W dniu 10 września okupant przeprowadził obławę w dzielnicach Zawodzie i Kucelin na mężczyzn w wieku 18-45 lat. Przez szereg dni zatrzymani byli więzieni w nieludzkich warunkach, potem 700 osób wysłano do obozów dla „cywilnych jeńców wojennych” (Zivilgefangenen) w Dreźnie, w okolicach Magdeburga i w Ostrzeszowie, przemianowanym przez Niemców na Schildberg. W dziejach miasta ten dzień nazwano czarna niedziela (Dubicki, Majzner 2006, Grządzielski 2006, Pietrzykowski 1985, 1987, Zbudniewek 1991).

\section{5.}

W pierwszych dniach września media polskie (radio, prasa codzienna) podały wiadomość, która poraziła Polaków: klasztor jasnogórski został zburzony, a los cudownego obrazu jest nieznany. Informacja ta miała wszelkie cechy prawdopodobieństwa, jako że jeszcze przed wojną szerzono wieść, że Adolf Hitler zamierzał Jasną Górę zrównać z ziemią. Wiadomości o bombardowaniu sanktuarium Matki Bożej Częstochowskiej i jego zniszczeniu niemal natychmiast przedostały się do zagranicznych środków przekazu. Spróbujmy prześledzić te informacje. Większość doniesień publikowały gazety warszawskie, które ukazywały się najdłużej (wojska niemieckie wkroczyły do stolicy dopiero 1 października). Poza gazetami stołecznymi informacje takie można odnaleźć w prasie krakowskiej, 
poznańskiej, lwowskiej, wileńskiej, lubelskiej, łódzkiej. W momencie wkroczenia do danego ośrodka wojsk niemieckich prasa polska przestawała się ukazywać.

Wspominaliśmy wyżej, że Częstochowa była bombardowana przez lotnictwo niemieckie 1 i 2 września, lecz klasztor poważnie nie ucierpiał w wyniku bombardowań. Mimo to w dniu 2 września rząd otrzymał wiadomość o palącej się Jasnej Górze (Michalski 2014). Ciąg publikacji prasowych o sytuacji w Częstochowie i na Jasnej Górze rozpoczął 3 września krakowski dziennik „Tempo Dnia” (nr 243: 2). Opierając się na komunikacie podanym w języku niemieckim w Polskim Radio, gazeta pisała: „Czy Niemcy wiedzą, że w dniu wczorajszym bombowce niemieckie dokonały nalotu na Częstochowę, że obrzuciły bombami miasto, które jest polskim Lourdes? Niemieccy lotnicy strzelali z karabinów maszynowych do ewakuowanej ludności cywilnej, strzelali do Sióstr Miłosierdzia i lekarzy". W następnych dniach podobne informacje były coraz liczniejsze. Wszystkie jednoznacznie oceniały Niemców. Świadczą o tym tytuły doniesień prasowych z 4 września: Zbrodnicza ręka hitlerowskiego barbarzyńcy nie zawahała się obrzucić bombami Jasna Górę - święty relikwiarz Polaków („Express Poranny” nr 244: 1, „Dzień Dobry!” nr 244: 1) (ryc. 5); Śmierć i zniszczenie złoczyńcom, którzy zbombardowali Jasną Górę („Wieczór Warszawski” nr 250: 1) (ryc. 6); Niemcy zbombardowali kościót i klasztor na Jasnej Górze. Bezprzykładna zbrodnia krwawych barbarzyńców („Głos Lubelski” nr 243: 1) (ryc. 7); Łuna nad Jasna Góra od bomb barbarzyńców wstrząnęła sumieniem świata („Dobry Wieczór! Kurier Czerwony” nr 244: 1) (ryc. 8). Podobne tytuły można

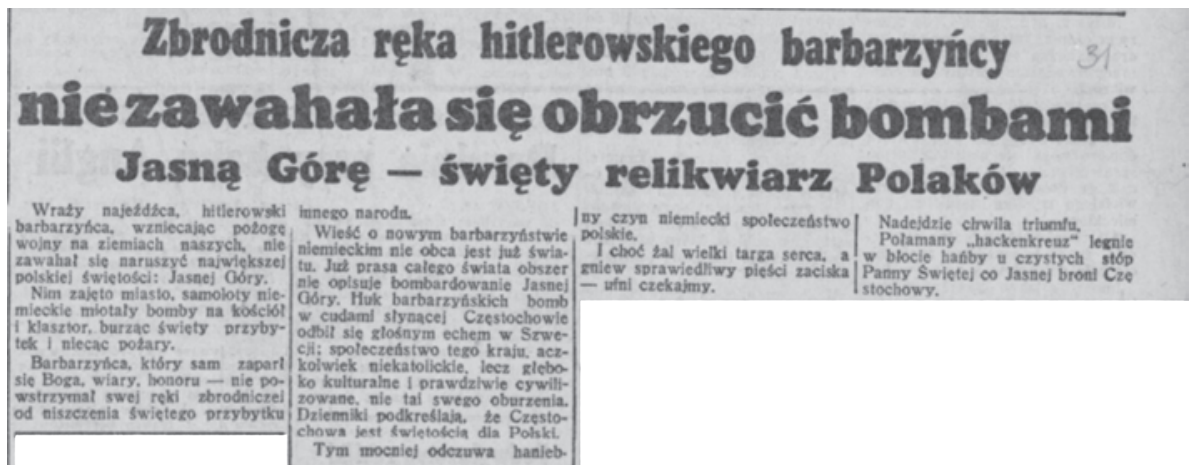

Ryc. 5. Fragment „Expressu Porannego” 4 września 1939, nr 244, s. 1 


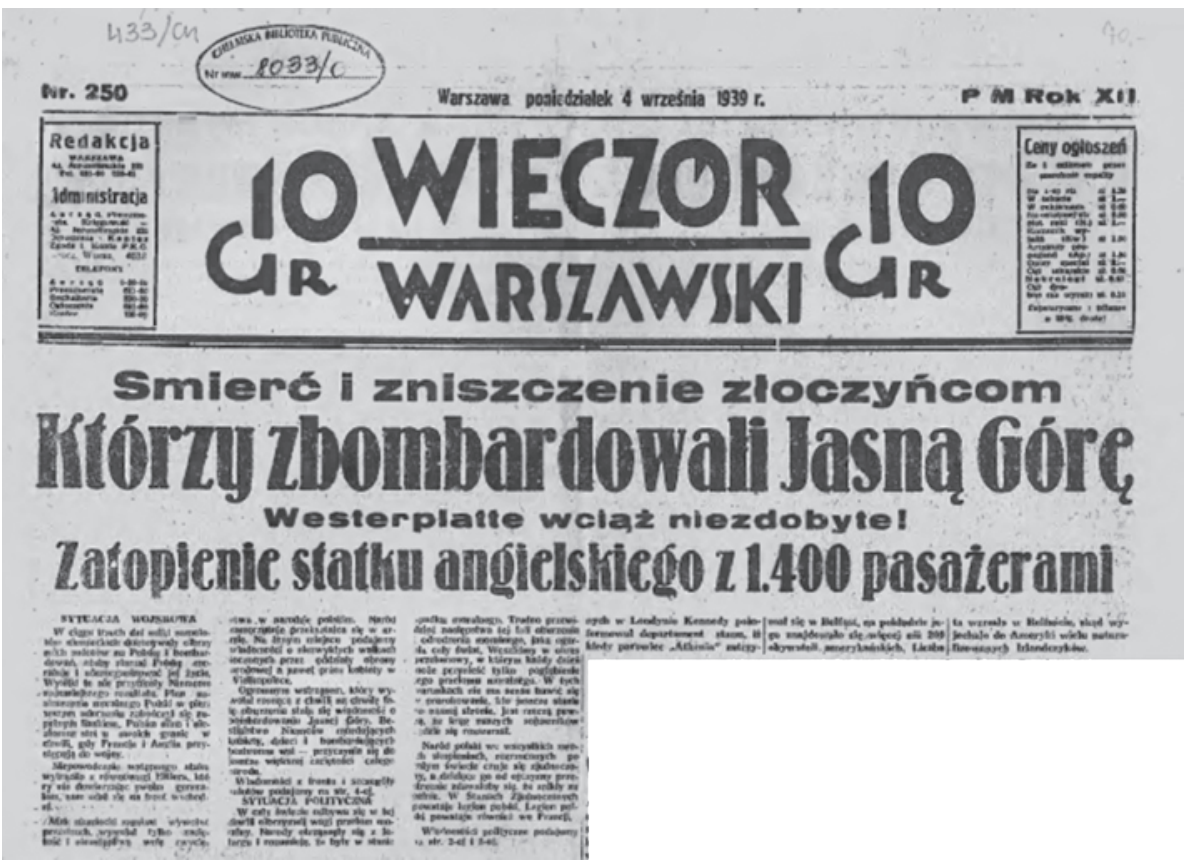

Ryc. 6. Fragment strony tytułowej „Wieczoru Warszawskiego” 4 września 1939 r., nr 250

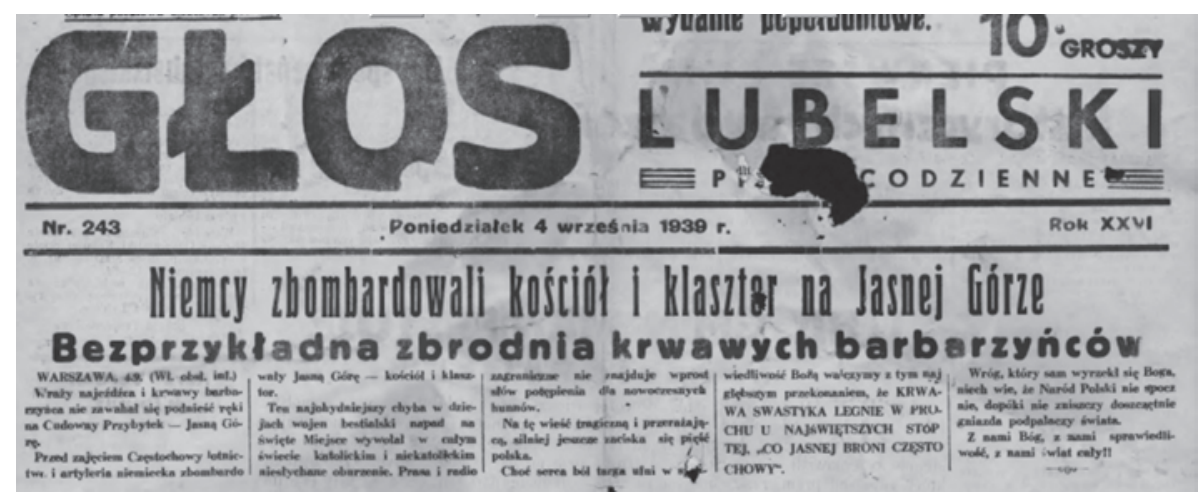

Ryc. 7. Fragment strony tytułowej „Głosu Lubelskiego” 4 września 1939 r., nr 243 


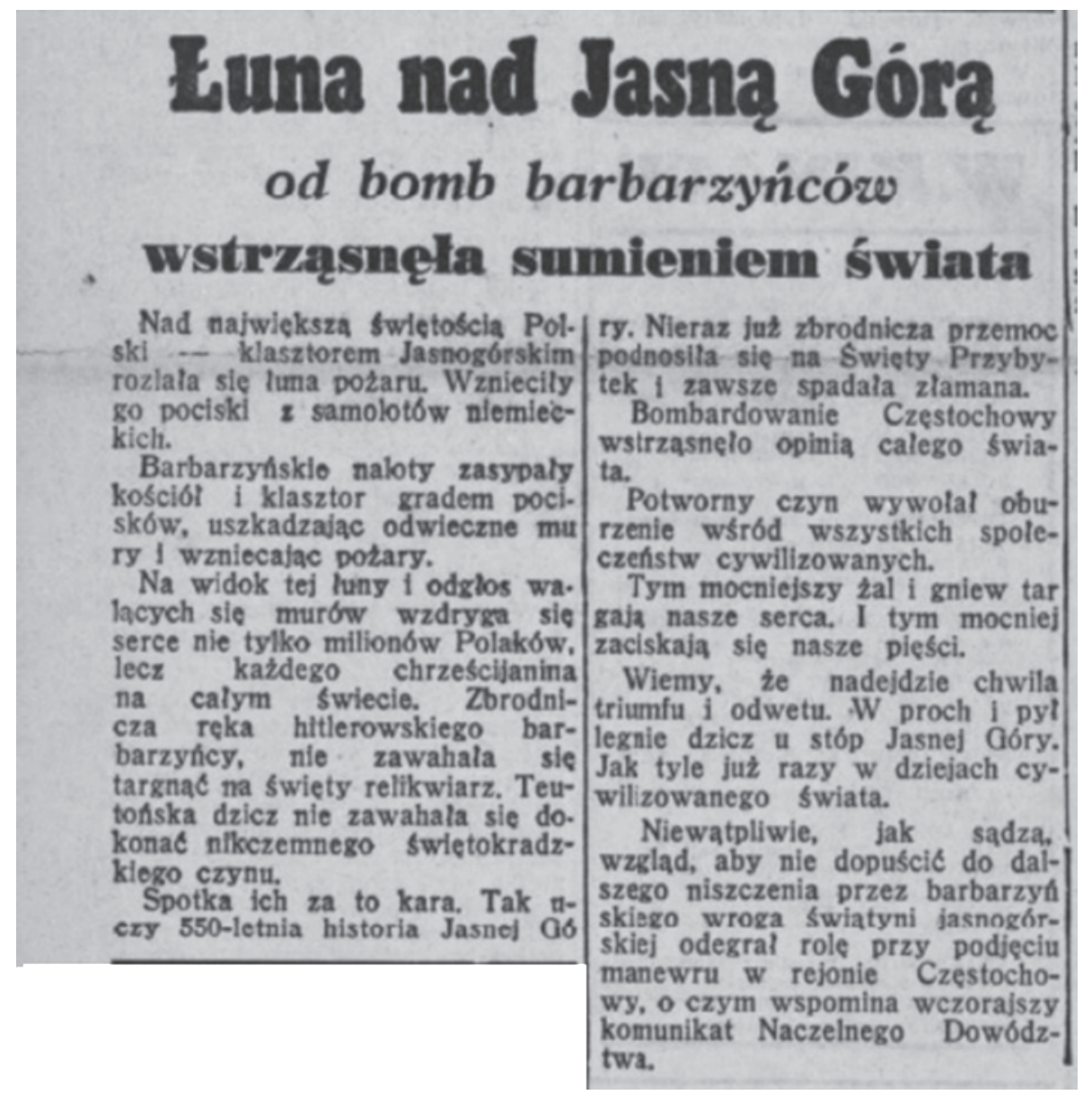

Ryc. 8. Fragment strony tytułowej pisma „Dobry Wieczór! Kurier Czerwony” 4 września 1939 r., nr 244

napotkać w gazetach z 5 września: Ohydne świętokradztwo! Świat katolicki oburzony bombardowaniem Jasnej Góry („Głos Powszechny” nr 246: 2); Fale gniewu w całym świecie wzbudziło bezecne sprofanowanie Jasnej Góry przez barbarzyńskie hordy germańskie („Goniec Warszawski” nr 247: 1-2) (ryc. 9). Równocześnie w nagłówkach prasowych z 5 września zaczęto wskazywać inne szczegóły związane z rzekomym zniszczeniem i profanacją Jasnej Góry, m.in.: Konie i żołdactwo niemieckie w świątyni jasnogórskiej („Dobry Wieczór! Kurier 


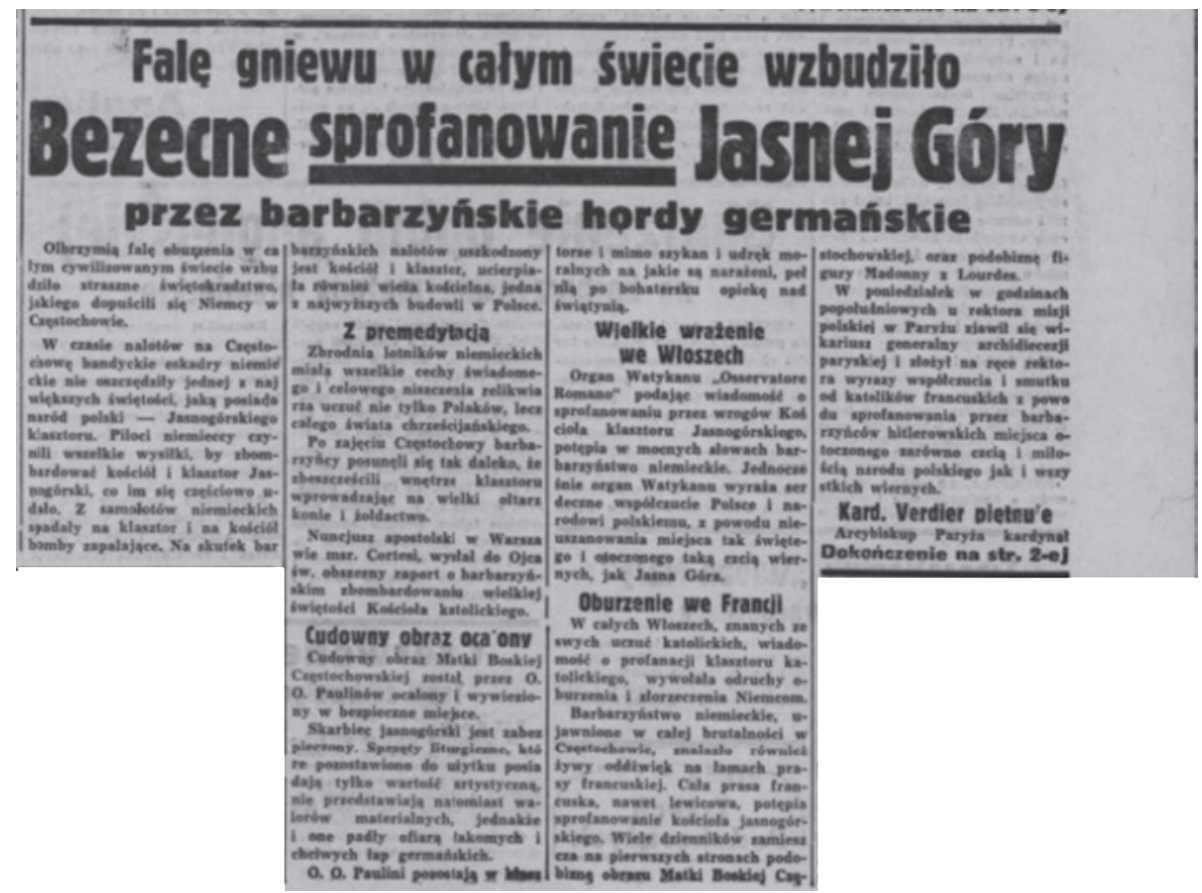

Ryc. 9. Fragment strony tytułowej „Gońca Warszawskiego” 5 września 1939 r., nr 247

Czerwony" nr 245: 2) (ryc. 10); Barbarzyństwo lotnictwa hitlerowskiego. Konie i żołnierze niemieccy $w$ kościele na Jasnej Górze. Cudowny obraz $w$ bezpiecznym ukryciu („Kurier Poranny” nr 243: 1); Raport nuncjusza do Ojca św. o bombardowaniu Częstochowy (,Wieczór Warszawski” nr 251: 2) (ryc. 11); Raport o bombardowaniu Częstochowy wysłał nuncjusz do Ojca św. Skarbiec Jasnogórski zabezpieczony („Express Poranny” nr 245: 1). W tym samym dniu, jak również 6 września zaczęły się pojawiać wiadomości dotyczące cudownego obrazu Matki Bożej: Ocalenie obrazu Królowej Korony Polskiej („ABC. Nowiny Codzienne” nr 257: 1; „Warszawski Dziennik Narodowy” nr 245 :1); Cudowny Obraz Matki Boskiej strzeże nadal Jasnej Góry („Goniec Warszawski” nr 248: 1); Wieża Jasnogórska rozbita. Cudowny obraz ocalony. (Od naocznego świadka) („Wieczór Warszawski” nr 252: 1); Obraz Królowej Korony Polskiej pozostał nie uszkodzony na Jasnej Górze („Czas-7. Wieczór” nr 246: 1). Od 4 września zamieszczano również informacje o reakcji międzynarodowej na 


\section{Konie so miasta prrer Niemedo: \\ Prrylezdal al potwierdrala u niemieckie dovodrtwo i toldac-

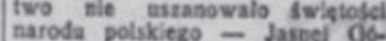 ry. niem. \\ Piekna prred a laty odbedon wank po botarze wieta fviaty. wi iasnogorskiel - aajwytsza a westala powalnie uszkodzons. ipo skroctenle toldactwo no \\ Klasztor Jamozorskt, rostat obrzacony gradem pociskow

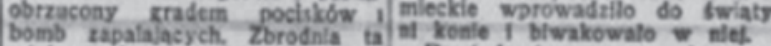 mials cechy sisteliclezo rormyi neco niszcreala cacrogel przes tht narod bolskt I caly iwlat kato. ikeki diatyat. \\ Jak informala osoby prrybyle Ronle I blwakowato $w$ nitet. Powiadomioay o sprolanowa. nla iwiatyni iasnorbrakle! nua- restocbowy do Warsiavy w} w swiqtyni jasnogorskiej

Do Warszasy praybylo kika đele wezoralszym cedowny of clusz apostolskt muz. Cortes! wy

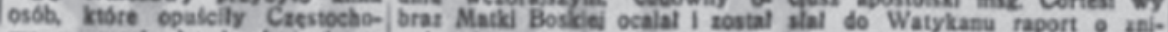

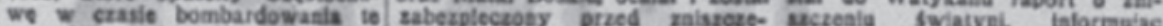

wiadomości z Częstochowy: Arcybiskup Paryża protestuje przeciwko barbarzyństwom niemieckim („IKC” nr 245: 1); Wobec całego świata Kardynat Paryża protestuje przeciw zbombardowaniu Jasnej Góry (,Wieczór Warszawski” nr 251: 2); Włosi oburzeni bombardowaniem klasztoru na Jasnej Górze („Słowo” Wilno, nr 244: 2); Kardynat Verdier wobec zbombardowania Częstochowy (tamże), Barbarzyńskie bombardowanie Częstochowy. Protest kardynata Verdier, arcybiskupa Paryża („Gazeta Polska” nr 248: 1); Bombardowanie Jasnej Góry przygnębiło katolików niemieckich (,Słowo” Wilno nr 245: 4); Polskie Lourdes w płomieniach. Krzyk straszliwego wzburzenia w całym świecie („Kurier Poranny” nr 246: 3; nr 30A: 1). Po raz ostatni motyw jasnogórski pojawił się 10 września. Publikując materiały o Jasnej Górze, redakcje powoływały się zazwyczaj na Polską Agencję Telegraficzną (PAT). Niekiedy informacje pochodziły od własnych korespondentów.
Oka $5 \%$, it 00 . Kapesyal potu stall a straty cudowsego obrara I pamlatkowed iviatyni

W kolach watykadskich przy. Duszcraja te Oiclec $5 \mathrm{w}$. skorze sta $z$ pierwasej nadarajacel sle vosobsoscl aby dad oebliczny vyraz swym ecroclom.

Prawdopodobaio okanje taka da wrecreale listow awierrytelnialacych przes ambasadora belcilikiega.

Sprotanowante felatyel lasnorornkiel wywotalo wielicie viratenie w cafym Swecle katolickim. Oberze! i Prancil dat myrax kardyal Verdier.

Motemy - wolal kardynat Vero der - nasmel bolaterskleh bract Polakbo rapewnic. te skrwawlone serce Cudowed Marki Crestochow sklet kiore wywarto tak olbrizy. nie vratenle w calym swiecle chrackelaiskim. pobodr lo nas do charcenla ra brod $w$ obronle naf clemestarn'tisrych rasad woloc-

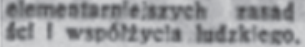

Wratenite w Belgil

BRUKSELA st. - Wadonotd a boenbardowaris Cisstocbewy orve

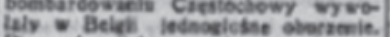

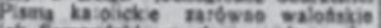
ak famasdrile = otaiernych anyka lach stwierdaia fait te beenty no cane a Ciestochowe byty ale tyko

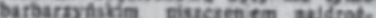

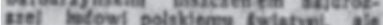

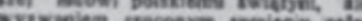
co cartescijaftstos. So cariescijatistwa.

Socialistycasy te Peole" videi $\%$

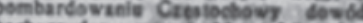

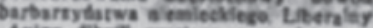

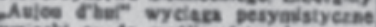

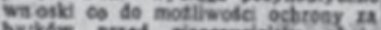

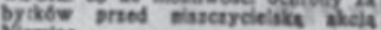
Niemiec.

\section{- $\mathrm{W}$ Sxwecfl}

strochous, se - Pras nofa!

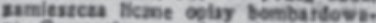
a. Catsocbowy pod bytulani fak mo.

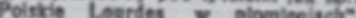

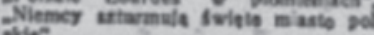

olient.

Ryc. 10. Fragment pisma „Dobry Wieczór! Kurier Czerwony" 5 września 1939 r., nr 245, s. 2 


\section{Raport nuncjusza do Ojca sw. 0 bombardowaniu Caęstochowy}

Obszerny raport o barbarzyn̂- ski, ueierpiała równiez wieża koskim bombardowaniu Częstochowy wysłał do Ojea §́w. nuncjusz apostolski w Warszawie, msr.

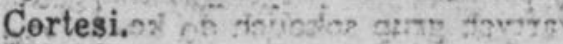

Organ Watykanu "Osservatore Romano" w bardzo stanowezym tonie potępia niemiecką agresję i barbarzyństwo. Natomiast w gorących slowach wyraża pełne wspólczucie Polsce i narodoxi polskiemu z powodu bombardowania Iudnosci cywilnej nieuszanowania świętego miejsca Jasnej Góry.

Skutkiem nalotów uszkodzony jest kościo\} i klasztor Jasnogor-| klasztorze.

Ryc. 11. Fragment „Wieczoru Warszawskiego” 5 września 1939 r., nr 251, s. 2

Nie jest naszym zamierzeniem analizowanie treści poszczególnych doniesień. Najczęściej mówią o tym same tytuły. Pragniemy jedynie zwrócić uwagę na swoisty fenomen funkcjonowania przez ponad tydzień tej nieprawdziwej przecież wiadomości, która zazwyczaj pojawiała się na pierwszych stronach gazet. Zapewne inicjatorzy tego przedsięwzięcia doskonale wiedzieli, jaką rangę ma w Polsce Jasna Góra i cudowny obraz Matki Bożej i jaką rolę odgrywa w procesie cementowania świadomości narodowej. Potwierdza to m.in. forma wydrukowania przez „Czas -7. Wieczór” w dniu 1 września (nr 243: 1) orędzia Prezydenta RP Ignacego Mościckiego: w delikatnie zakreślonej ramce miejsce centralne zajmuje sam tekst, po jego prawej stronie zamieszczono Godło Państwowe - Orła, a po lewej wizerunek Matki Bożej Częstochowskiej (ryc. 12). Przyjrzyjmy się zatem kilku tekstom.

Obszerna informacja pt. Łuna nad Jasna Góra od bomb barbarzyńców wstrzasnęła sumieniem świata („Dobry Wieczór! Kurier Czerwony” nr 244: 


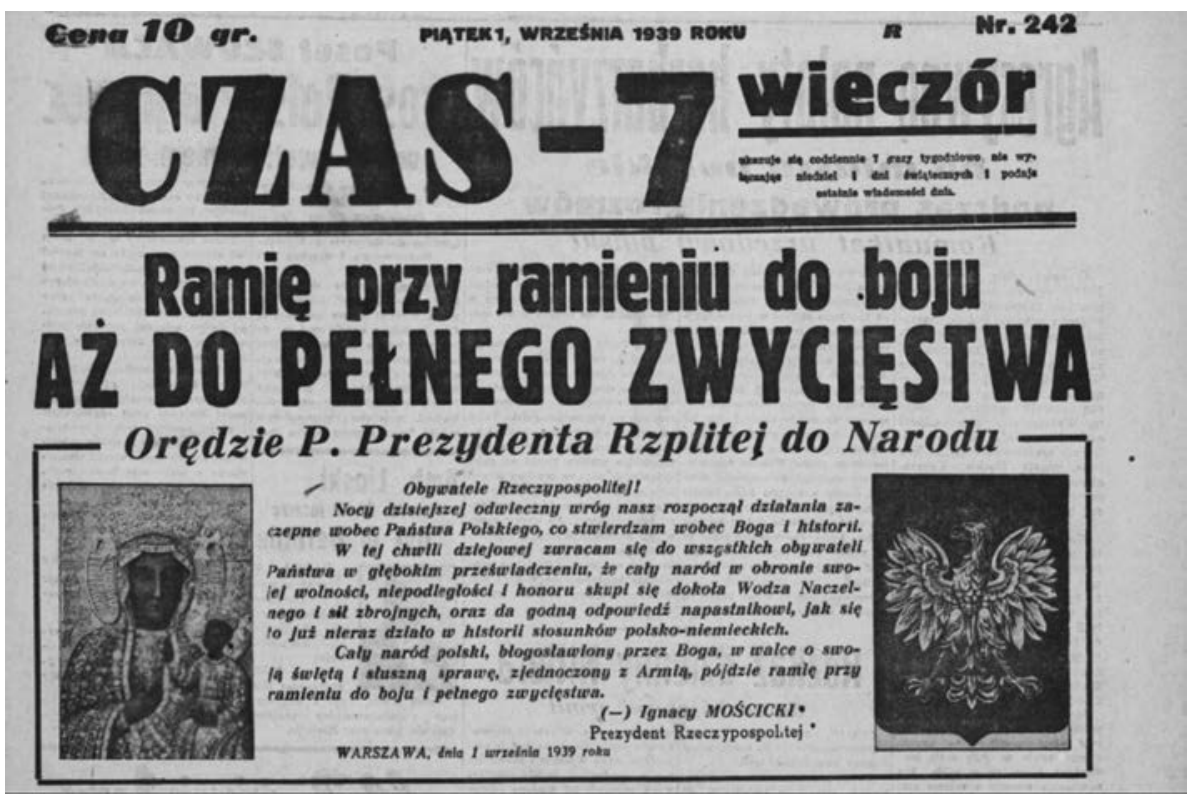

Ryc. 12. Fragment strony tytułowej pisma „Czas - 7. Wieczór” 1 września 1939 r., nr 242

1 z 4 września) zawierała tekst bardzo radykalny: „Nad największą świętością Polski - klasztorem Jasnogórskim rozlała się łuna pożaru. Wznieciły go pociski z samolotów niemieckich. Barbarzyńskie naloty zasypały kościół i klasztor gradem pocisków, uszkadzając odwieczne mury i wzniecając pożary. Na widok tej łuny i odgłos walących się murów wzdryga się serce nie tylko milionów Polaków, lecz każdego chrześcijanina na całym świecie. Zbrodnicza ręka hitlerowskiego barbarzyńcy nie zawahała się targnąć na święty relikwiarz. Teutońska dzicz nie zawahała się dokonać nikczemnego świętokradzkiego czynu. Spotka ich za to kara. Tak uczy 550-letnia historia Jasnej Góry. Nieraz już zbrodnicza przemoc podnosiła się na Święty Przybytek i zawsze spadała złamana. (...) Potworny czyn wywołał oburzenie wśród wszystkich społeczeństw cywilizowanych. Tym mocniejszy żal i gniew targają nasze serca. I tym mocniej zaciskają się nasze pięści. Wiemy, że nadejdzie chwila triumfu i odwetu. W proch i pył legnie dzicz u stóp Jasnej Góry. Jak tyle już razy w dziejach cywilizowanego świata".

Podobny wydźwięk miała wiadomość publikowana w „Expressie Porannym” w dniu 4 września (nr 244: 1) pt. „Zbrodnicza ręka hitlerowskiego barbarzyńcy 
nie zawahała się obrzucić bombami Jasną Górę - święty relikwiarz Polaków. Redakcja pisała: Wraży najeźdźca, hitlerowski barbarzyńca, wzniecając pożoge wojny na ziemiach naszych, nie zawahał się naruszyć największej polskiej świętości: Jasnej Góry. Nim zajęto miasto, samoloty niemieckie miotały bomby na kościół i klasztor, burząc święty przybytek i niecąc pożary. Barbarzyńca, który sam zaparł się Boga, wiary, honoru - nie powstrzymał swej ręki zbrodniczej od niszczenia świętego przybytku innego narodu. Potem czytelnicy zostali poinformowani o reakcjach światowych na to wydarzenie. Tekst zakończono słowami: I choć wielki żal targa serca, a gniew sprawiedliwy pięści zaciska - ufni czekajmy. Nadejdzie chwila triumfu. Połamany "hakenkreuz” legnie w błocie hańby u czystych stóp Panny Świętej co Jasnej broni Częstochowy”.

Tekst zatytułowany Wieża jasnogórska rozbita. Cudowny obraz ocalony („Wieczór Warszawski” nr 252: 1 z 6 września) zawiera informację uzyskaną od „naocznego ? świadka”, niejakiego Ludomira Kucharskiego, mieszkańca Częstochowy. Według tej relacji 2 września około godz. 9 rano 29 niemieckich bombowców zaatakowało Jasną Górę. Nalot trwał przez dwie godziny. Powtórne bombardowanie było skierowane na wieżę jasnogórską, która w wyniku tego miała runąć 3 września. Zostały zniszczone witraże, rzeźby, obrazy. Całość tego doniesienia redakcja kończy słowami: „Wiadomość o zbeszczeszczeniu Jasnej Góry wywarła wśród kobiet płacz, u mężczyzn jeszcze większą zaciętość (...)".

Pojawiały się też wieści, że „żołdactwo niemieckie wprowadziło do świątyni konie i biwakowało w niej” („Dobry Wieczór. Kurier Czerwony” nr 245: 2 z 5 września).

Równocześnie od 5 września ukazywało się coraz więcej informacji o tym, że pomimo zniszczeń samego klasztoru cudowny obraz Matki Bożej ocalał. W „ABC. Nowiny Codzienne” (nr 257: 1) czytamy m. in.: „(...) cudowny obraz Królowej Korony Polskiej ocalał. Na przestrzeni tysiącletniej naszej historii niejednokrotnie już ręka wroga podnosiła się bluźnierczo na cudowny wizerunek. Niemcy, Szwedzi i Rosjanie, a obecnie znowu Niemcy śmieli targnąć się na narodową relikwię. Jasna Góra wytrzymywała zawsze najcięższe próby, kt óre przechodziła wraz z całym Narodem Polskim. Cudowne ocalenie obrazu Najśw[iętszej] Marii Panny wskazuje, iż i tym razem przed nami jest zwycięstwo". Relacje w innych gazetach podkreślają rolę paulinów jako opiekunów obrazu. Dodajmy, że przez pewien czas wierzono w opowieść, że cudowny obraz został wywieziony do Warszawy, potem pojawiła się wieść, że znajduje się on w paulińskim klasztorze w Leśniowie. 
Wieści związane z Jasną Górą prędko przedostały się do opinii międzynarodowej. Najbardziej zdecydowane stanowisko wobec ataku niemieckiego na klasztor zajęła Francja, a zwłaszcza tamtejszy Kościół. W tej sprawie zabrał głos m.in. kardynał Jean Verder (1864-1940), od 1929 r. arcybiskup Paryża, zdecydowany przeciwnik faszyzmu. „Ilustrowany Kurier Codzienny” (nr 245: 1 z 4 września) doniósł, że już 3 września złożył on kondolencje na ręce rektora misji polskiej w Paryżu z powodu bombardowania Jasnej Góry, nazywanej przez niego „polskim Lourdes”. Nazajutrz w przejmującym przemówieniu radiowym wystosował do całego świata protest wobec ataku na klasztor i zwrócił się do Francuzów z apelem: „Nasza Najświętsza Maria Panna z Lourdes, tak czczona we Francji, doznała w polskim Lourdes pierwszego ciosu ze strony naszych wrogów. Co za ohydne świętokradztwo. Składam hołd i podziw Polakom, którzy tak bohatersko walczą za wolność swoją, za wolność naszą i za wolność świata” („Wieczór Warszawski” nr 251: 2 z 5 września). Dalej mówił: „Zapewniamy naszych braci Polaków, że skrwawione serce Cudownej Matki Boskiej Częstochowskiej pobudziło nas do uchwycenia za broń w słusznej obronie najbardziej elementarnych zasad wolności i współżycia ludzkiego” („Goniec Warszawski” nr 247: 2 z 5 września). Potępienie wyraziły również liczne francuskie organizacje społeczne, m.in. centrale związków zawodowych. Wiadomości z Częstochowy zamieszczała na czołowych miejscach prasa francuska (m.in. komunistyczna), belgijska (w tym również socjalistyczna) i szwedzka (m.in. dając takie tytuły zamieszczanym tekstom: Polskie Lourdes w płomieniach; Niemcy szturmuja święte miasto polskie), norweska, włoska, amerykańska. Wiele dzienników francuskich na pierwszych stronach zamieszczało podobiznę obrazu Matki Bożej Częstochowskiej, umieszczoną obok fotografii figury Matki Bożej z Lourdes („Goniec Warszawski” nr 247: 1 z 5 września). Wydarzenia w Częstochowie miały się również odbić echem w samych Niemczech. Donosiło o tym wileńskie „Słowo” (nr 245: 4) z 6 września: „Pomimo zakazu słuchania radia zagranicznego wiadomość o zbombardowaniu Jasnej Góry rozeszła się w Niemczech zadziwiająco szybko. Powstały na tym tle ruch wśród katolików austriackich i bawarskich tłumi Gestapo z całą bezwzględnością. Aresztowano kilku księży (...)". Na napaść Niemców na Jasną Górę ostro zareagował też nuncjusz papieski w Polsce Filippo Cortesi (1876-1947). Wprawdzie Polskę opuścił już 5 września, zdążył jednak wcześniej wysłać specjalny raport w tej sprawie do papieża Piusa XII. O wypadkach na Jasnej Górze informował też oficjalny organ Stolicy Apostolskiej „L'Osservatore Romano”, który „(...) w gorących słowach wyraża pełne współczucie Polsce i narodowi polskiemu z powodu bombardowania 
ludności cywilnej [i] nieuszanowania świętego miejsca, Jasnej Góry” („Express Poranny" nr 245: 1 z 5 września).

Wątek jasnogórski w prasie polskiej kończy artykuł pt. Ratujmy kościoły nasze! biskupa sufragana archidiecezji wileńskiej Kazimierza Mikołaja Michalkiewicza (1865-1940), zamieszczony 10 września w „Słowie” (nr 249: 6) Wymieniając szkody, jakie poniosły niektóre świątynie polskie w wyniku dotychczasowych działań wojennych, pisał m.in.: „Klasztor Jasnogórski w Częstochowie był bombardowany, choć stał daleko od budynków wojskowych. Cudowny obraz Najświętszej Panienki ocalał tylko dlatego, że Ojcowie Paulini zawczasu ukryli go w bezpieczne i tajemne miejsce". Później w zasadzie powracano już do tego tematu, choć jeszcze 12 września „Kurier Warszawski” (nr 262: 2, wyd. wieczorne) opublikował listę ofiarodawców na rzecz odbudowy Jasnej Góry. Temat ten pojawił się przelotnie także w polskojęzycznej prasie niemieckiej.

\section{6.}

Niemcy bardzo szybko zareagowali na rozszerzające się wiadomości jasnogórskie. Sprawę tę zaczął osobiście nadzorować minister propagandy III Rzeszy Joseph Goebbels. W trybie pilnym wysłał do Częstochowy radcę ministerialnego

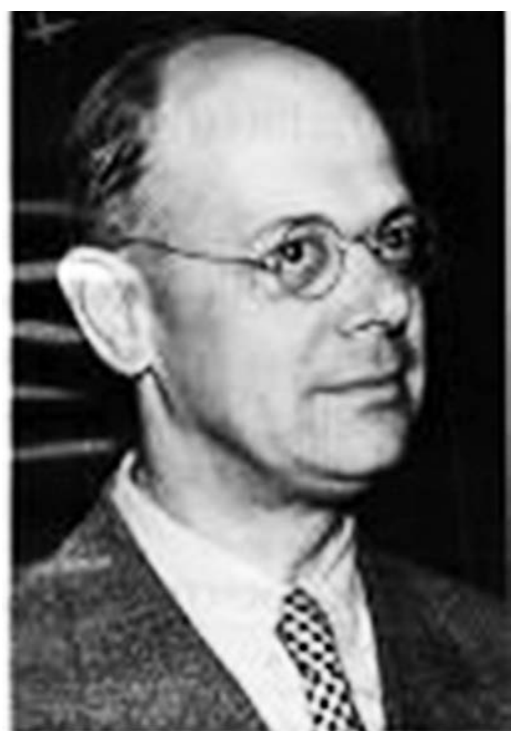
G. W. Müllera. Oprócz dwóch wojskowych towarzyszył mu również światowej sławy amerykański dziennikarz Ludwig „Louis” Paul Lochner (1887-1975), laureat Nagrody Pulitzera w 1939 r. za korespondencje z nazistowskich Niemiec (ryc. 13). Od 1924 r. był on korespondentem Associated Press w Berlinie. Długoletni pobyt $\mathrm{w}$ tym mieście ułatwiał

Ryc. 13. Ludwig "Louis” Paul Lochner (1887-1975) korespondent Associated Press w Berlinie (https://www.pinterest.com/ pin/8539951480600117615/

(dostęp: 25. 06. 2017) 
fakt, że jego żona była z pochodzenia Niemką. Na prośbę (rozkaz?) Goebbelsa miał poświadczyć międzynarodowej opinii publicznej, że klasztor jasnogórski stoi nieuszkodzony, a cudowny obraz nadal jest dostępny dla wiernych. Müller oraz Lochner dostali do dyspozycji wojskowy samolot, którym wczesnym rankiem 4 września odbyli podróż z lotniska Tempelhof w Berlinie do bliżej nieokreślonej miejscowości na Śląsku. Dalszą drogę przebyli czarną limuzyną, którą zajechali na Jasną Górę około 9 rano (ryc. 14). Od przeora N. Motylewskiego zażądali własnoręcznie napisanego poświadczenia, że klasztor nie doznał uszczerbku.

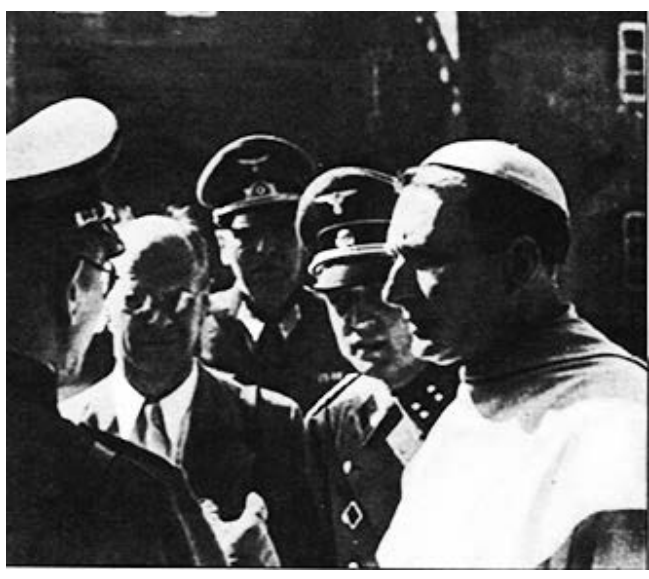

Ryc. 14. Przeor Jasnej Góry N. Motylewski w rozmowie z L. P. Lochnerem, Jasna Góra 4 września 1939 r. (https://www.googleadservices.com/pagead/aclk?sa $=\mathrm{L} \& a i=C Q K$ nYw_tgWaagOMmAygXHtY_QCe6mm_JI-fK4kYwFw-7Fryf (dostęp: 25. 06. 2017)

Dokument został sporządzony na oficjalnym formularzu klasztornym i potwierdzony pieczęcią oraz podpisem przeora. Oświadczenie to brzmiało (ryc. 15): „Niniejszym zaświadczam na żądanie Wojskowych Niemieckich Władz, iż Cudowny Obraz Matki Boskiej Częstochowskiej na Jasnej Górze ani przy wkroczeniu Wojsk wczoraj ani do chwili obecnej nie został uszkodzony. Jasna Góra też dotąd nie poniosła żadnych strat" (NAC, sygn. 2-228).

Tekst oświadczenia (tłumaczonego też na język niemiecki) został natychmiast rozkolportowany przez Niemców do gazet ukazujących się w III Rzeszy, a także przesłany do wielu agencji prasowych na całym świecie. W milionach egzemplarzy rozrzucano je z samolotów w Polsce i w wielu miejscach Europy. W publikowanych materiałach propagandowych bardzo często tekstowi samego oświadczenia towarzyszyło zdjęcie Lochnera w kaplicy przed cudownym obrazem Matki Bożej Częstochowskiej, a także „odpowiedni” komentarz, zapewne napisany przez Müllera. W jednej z takich ulotek Niemcy pisali (ryc. 16):

„Polacy! Wasza prasa i radio, które stają w służbie kłamliwego rządu warszawskiego okłamali Was, donosząc, że wojsko niemieckie ostrzelało i zniszczyło 


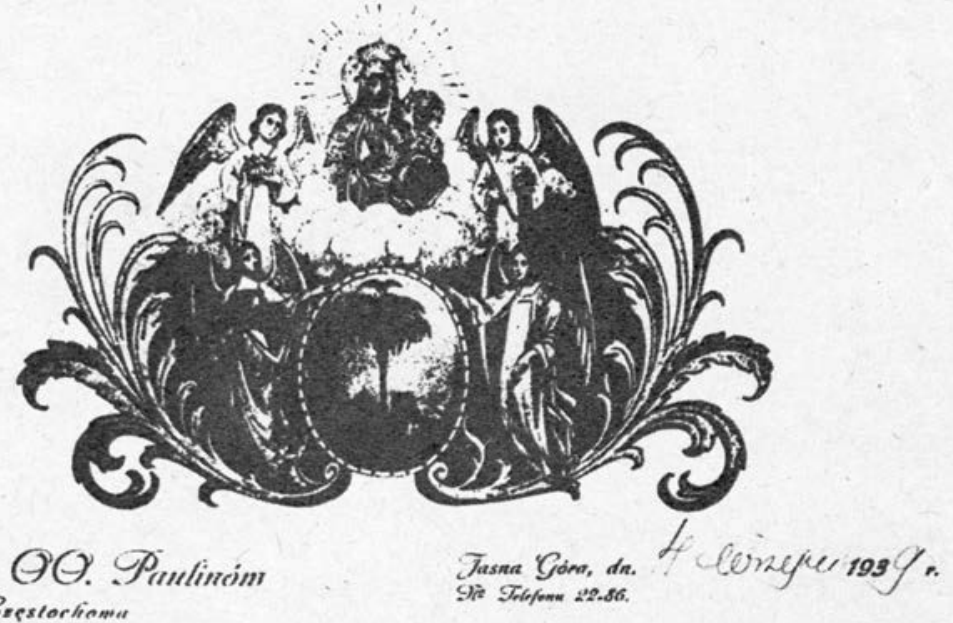

Tilusstor $\Theta \Theta$. Prulinim

Crestorliomu"

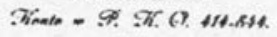

Tiिuерizyu worialejam na zgaa

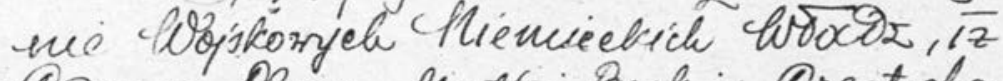

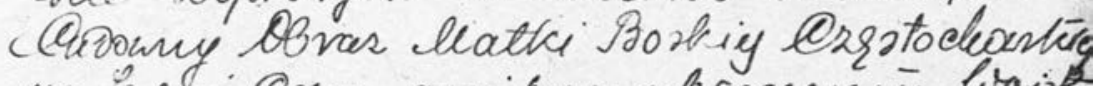

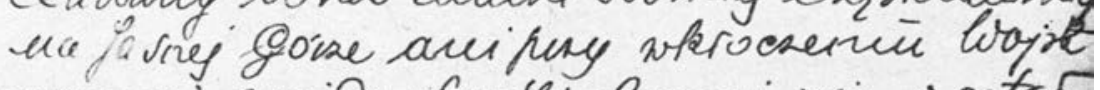
werovaj anido druili obecry rive sostar

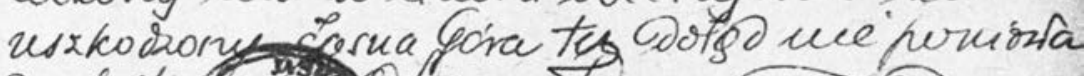
zcompcle strats

Ryc. 15. Oświadczenie przeora N. Motylewskiego przekazane Niemcom 4 września 1939 r. (NAC sygn. 2 - 228)

cudowny obraz Matki Boskiej Częstochowskiej. To jest kłamliwa wiadomość, wymyślona przez Wasz rząd po to, aby pobudzić Was do nienawiści przeciw Niemcom. Znany dziennikarz amerykański L. P. Lochner odwiedził w dniach 4. i 5. września klasztor i świątynię częstochowską, donosząc w prasie częstochowskiej co następuje: "Twierdzenie prasy zagranicznej, a specjalnie radia 


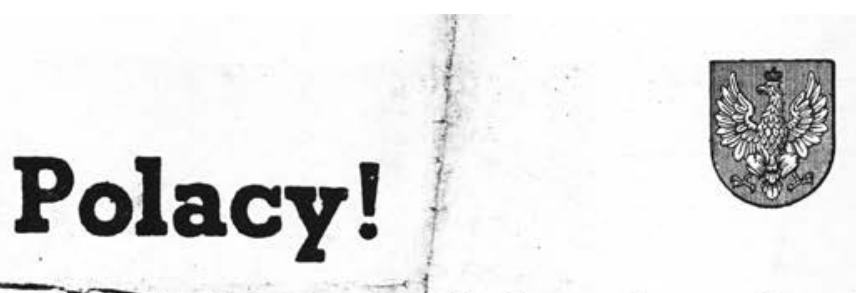

Wasza prasa.f radio, które stają w służbie kłamliwego rządu warszawskiego okłamali Was, donosząc, że wojsko niemieckie ostrzelało i

\section{zniszczylo cudowny obraz Matki Boskiej Częstochowskiej}

To jest kłamliwa wiadomość, wymyślona przez Wasz rząd po to, aby pobudzić Was do nienawiści przeciw Niemcom.

Znany dziennikarz amerykański L. P. Loehner odwiedzil w dniach 4. i 5. września klaszlor i swiątynię ezęstochowską, donosząe w prasie amerykańskiej, co następuje:

„Twierdzenia prasy zagranicznej, a specjalnie radia polskiego o uszkodzeniu obrazu Matki - Boskiej Czẹstochówskiej są czczym wymysłem. Osobiście przekonatem się o tym, że cudowny obraz jak i klaszlor w Częstochowie zupełnie ocalały. Tak, jai nrẹed lym wszysey zakonnic spelniają w klasztorze swoją służbe $\mathbf{i}$ odprawiają codziennie swoje nabożeństwa.“

Poniżej zamieszczamy fotografię ołtarza z wizerunkiem Matki Boskiej wnẹtrza światyni klasztornej w Czẹstochowie. Zdjẹć tych dokonano w dniu 5. września 1939. $r$.

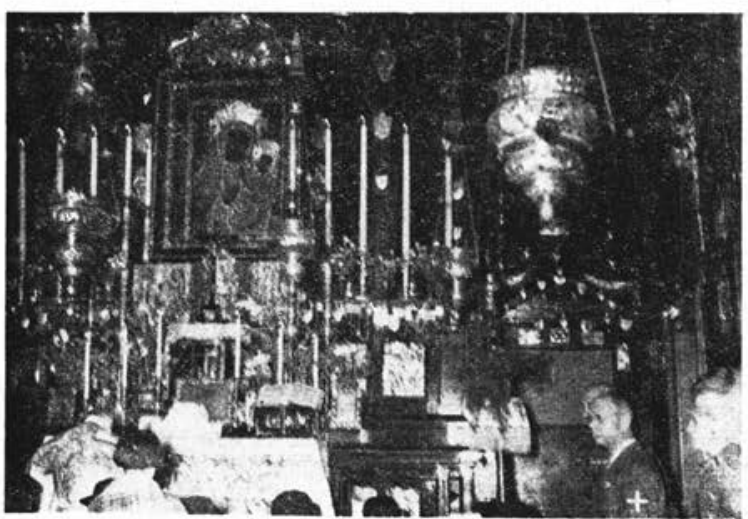

Cudowny obraz Matki Boskiej Częstochowskiej nietylko nie jest zniszczony, lecz znajduje się, jak każda $z$ Waszych narodowych albo religijnych swiẹtości pod specjalną ochroną armii niemieckiej.

Po prawej dziennikarz amerykański L. P. Lochner i oficerowie niemieccy

ODEZWA NIEMCÓW Z WRZEŚNIA 1939.ROKU W SPRAWIE ZNISZCZENIA OBRAZU MATKI BOŻE ZE ZBDORÓW MUZZLM CZESTOCHOWSNECO

Ryc. 16. Jedna z ulotek kolportowana przez Niemców na temat Jasnej Góry (zbiory Muzeum Częstochowskiego) 
polskiego o uszkodzeniu obrazu Matki Boskiej Częstochowskiej są czczym wymysłem. Osobiście przekonałem się o tym, że cudowny obraz, jak i klasztor w Częstochowie zupełnie ocalały. Tak jak przedtem wszyscy zakonnicy spełniają w klasztorze swoją służbę i odprawiają codziennie swoje nabożeństwa". Poniżej zamieszczamy fotografię ołtarza z wizerunkiem Matki Boskiej wnętrza świątyni klasztornej w Częstochowie. Zdjęć tych dokonano w dniu 5. września 1939 r. Cudowny obraz Matki Boskiej Częstochowskiej nie tylko nie jest zniszczony, lecz znajduje się, jak każda z Waszych narodowych albo religijnych świętości pod specjalną ochroną armii niemieckiej”. W lewym rogu zamieszczono zdjęcie L. P. Lochnera i oficerów niemieckich w kaplicy (Zbiory Muz. Częstochowskiego). Tekst zawartego tutaj oświadczenia samego Lochnera tylko nieznacznie różni się od innej wersji, cytowanej przez J. Zbudniewka (1991: 87).

Według źródeł niemieckich Lochner pozostał w Częstochowie do 5 września. Wiadomo, że obok samej rozmowy z przeorem zwiedził Jasną Górę, przebywając przez dłuższy czas w kaplicy cudownego obrazu. Wizyta ta głęboko zapadła mu w pamięć. Wyraził to później w swoich pamiętnikach pisanych już w Nowym Jorku ${ }^{1}$ :

„W Częstochowie byłem w kaplicy klasztoru jasnogórskiego, aby upewnić się osobiście, czy sławny obraz Czarnej Madonny, który znajduje się tutaj od 1382 r., nie został zniszczony. Nigdy w życiu nie przeżyłem tego, czego doświadczyłem tutaj. Napotkałem tłum [?] wiernych z Polski, mężczyzn i kobiet, leżących na podłodze z rozłożonym rękoma, jakby były przybite do krzyża, i całujących zimną, marmurową posadzkę. Inni klęczeli, tylko swoją twarz przybliżali do podłogi. Jeszcze inni klęczeli i płakali, mając wzrok utkwiony w obrazie Czarnej Madonny. Ci mężczyźni i te kobiety byli w skrajnej rozpaczy, a swoją ostatnią nadzieję wiązali z Madonną. Wierzyli, że oddając Jej w opiekę swych synów, mężów, ukochanych w cudowny sposób zostaną oni im zwróceni" (Lochner 1943: 126; wolne thumaczenie A.J.).

Przypomnijmy, że w dniu, kiedy Lochner przebywał na Jasnej Górze, w Częstochowie miała miejsce masakra ludności cywilnej, a dzień ten nazwano czarnym poniedziałkiem. W mieście, a nawet $\mathrm{w}$ bezpośrednim sąsiedztwie wzgórza jasnogórskiego, słychać było pojedyncze wystrzały i salwy karabinowe.

1 Po przystąpieniu do wojny Stanów Zjednoczonych Lochner został przez Niemców internowany w dniu 11 grudnia 1941 r. Zwolniono go w maju 1942 r. w ramach wymiany jeńców. Wtedy też powrócił do Stanów. 
Trudno przypuszczać, aby tak bystry dziennikarz tego nie dostrzegł. Niestety, o tym wydarzeniu Lochner nie pisze w żadnej ze swych korespondencji. O sytuacji w mieście wspominał bardzo krótko, ograniczając się do wzmianki o uzbrojonych polskich cywilach, nazywanych przez niego nie wiadomo dlaczego „snajperami”, przeciwko którym Niemcy zorganizowali akcję wojskową (Snipers plague Hitler troops on East front, „Chicago Daily Tribune” 1939 nr 213C z 6 września; Reich Troops Hit at Polish Snipers [...] American Reporter on Eastern Front Sees Men Marched Off in Czestochowa, "The New York Times" 1939 nr 29 810). Z żalem wypomina mu takie podejście do sytuacji Polaków w Częstochowie wileńskie „Słowo” (1939, nr 248).

Po pobycie na Jasnej Górze Lochner powrócił na śląskie lotnisko, z którego 5 września odleciał do Berlina, wprost na zorganizowaną dla niego konferencję prasową. Dziennikarzy niemieckich i zagranicznych poinformował o tym, co zobaczył w klasztorze. Jego korespondencję na ten temat zamieściła też codzienna prasa amerykańska (m.in.: „Chicago Daily Tribune”, „The Daily Iowan”, "The New York Times” - wszystkie z 6 września) oraz tygodnik "Life” (19 września). Liczne relacje ukazały się również w gazetach niemieckich. Szczególną uwagę na to wydarzenie zwróciła gazeta „Völkischer Beobachter” (6 września), główny organ partyjny w III Rzeszy. Obok zdjęcia Lochnera w kaplicy zamieściła również komentarz G. W. Müllera. Napisał on m.in., że w wyniku wizyty dziennikarza amerykańskiego na Jasnej Górze „cały świat poinformowany został, że niemieccy żołnierze są lepsi od barbarzyńców niszczących dobra kultury (...), ale i tym razem nie powiodły się plany międzynarodowego kłamstwa” („Völkischer Beobachter” 1939, nr 249: 1 z 6 września. Cyt. za: Zbudniewek 2006: 463) (ryc. 17). W podobnym tonie pisała o tym polskojęzyczna prasa niemiecka. "Ilustrowany Kurier Codzienny" z dnia 23 września 1939 r. poświęcił temu niemal całą stronę (ryc. 18): Dnia 3 września twierdziło nasze radio, że Cudowny Obraz Matki Boskiej Częstochowskiej został zniszczony przez Niemców. To kłamstwo skończyło się jednak prędko. Dnia 5 września 1939 r. amerykański reporter F. P. Lochner przekonat sie osobiście, że Obraz Święty nie doznat żadnego uszkodzenia i klasztor na Jasnej Górze nie wykazał żadnych śladów zniszczenia („IKC” 1939 nr 254: 3). Tekstowi towarzyszą zdjęcia Lochnera w kaplicy oraz podczas konferencji prasowej w Berlinie, sylwety klasztoru oraz fotokopia oświadczenia przeora Motylewskiego. W „Ilustrowanym Kurierze Polskim” z 13 października (1939, $\mathrm{nr}$ 1: 2) zamieszczono zdjęcia Lochnera w kaplicy i podczas rozmowy z przeorem 


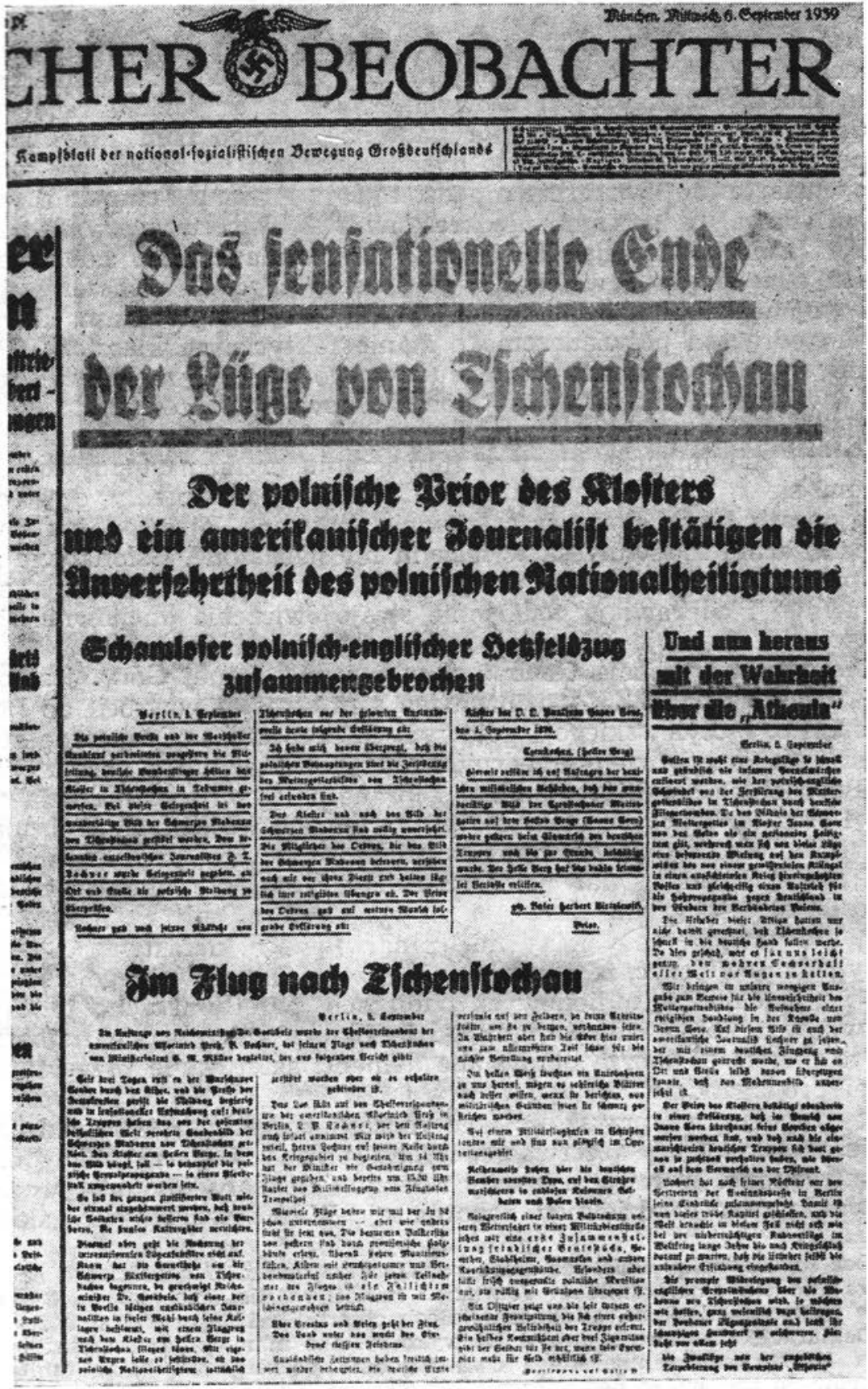

Ryc. 17. Fragment strony tytułowej pisma „Völkischer Beobachter” 6 września 1939 r., nr 249 


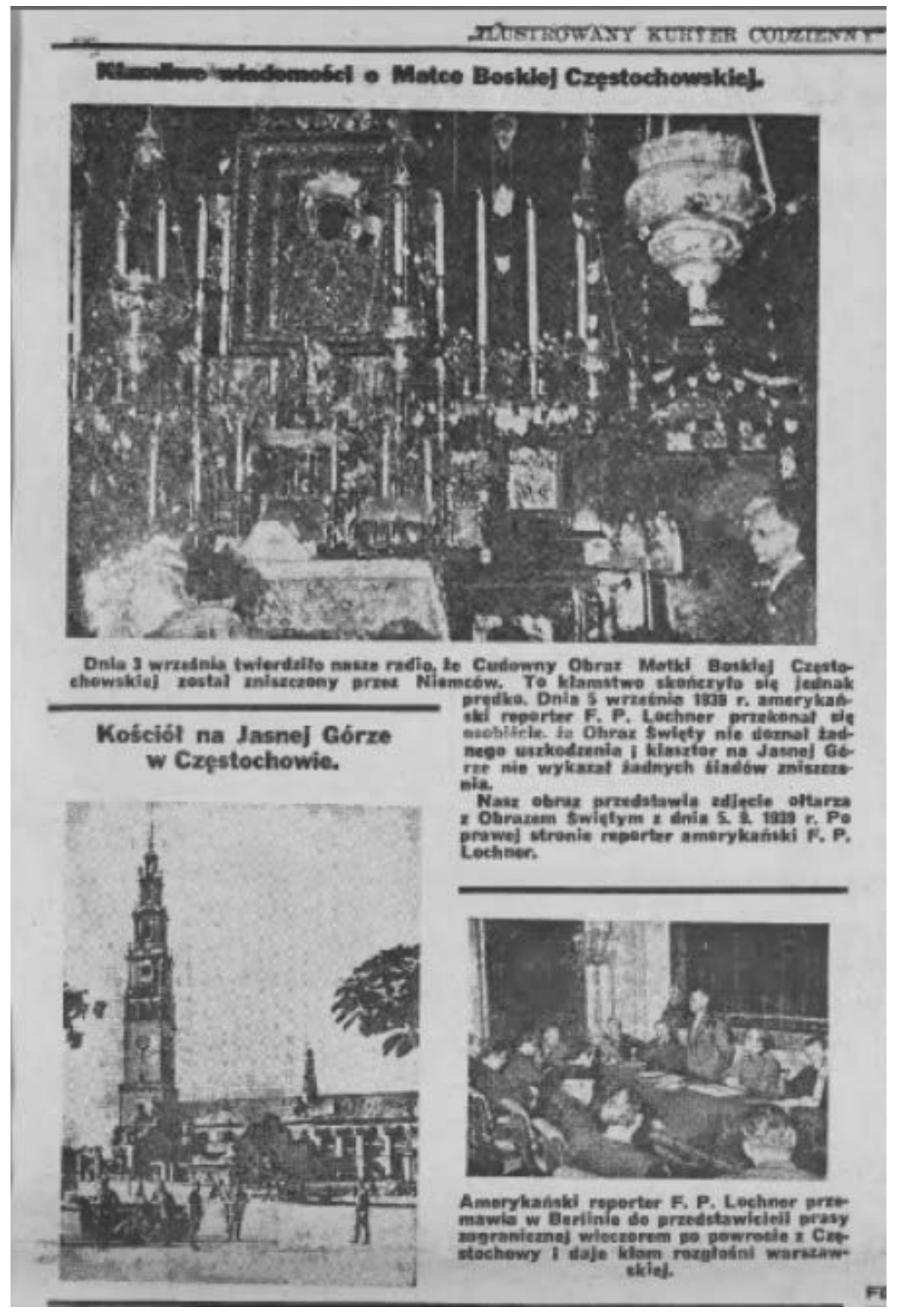

Ryc. 18. Fragment polskojęzycznego pisma niemieckiego „llustrowany Kurier Codzienny" 23 września 1939 r., nr 254, s. 3 
Motylewskim, podobiznę Matki Bożej Częstochowskiej oraz fotokopię oświadczenia przeora (ryc. 19). W krótkim komentarzu napisano: „Wiadomość o zniszczeniu obrazu Matki Boskiej w klasztorze Jasnogórskim w Częstochowie w pierwszych dniach wojny okazała się zwykłym kłamstwem. Ani klasztor, ani kaplica nie wykazują najmniejszych uszkodzeń. Doniósł o tym całemu światu dziennikarz amerykański Lochner, jako świadek naoczny. Fotografie nasze dowodzą, że nabożeństwa na Jasnej Górze odbywają się nadal bez przeszkód. Matka Boska Częstochowska nadal będzie nam udzielała Swego błogosławieństwa i Swej pomocy, której dziś szczególnie potrzebujemy".

W dniu 5 września późnym wieczorem niemiecka rozgłośnia radiowa we Wrocławiu nadała wywiad z przeorem Motylewskim, który został przeprowadzony dzień wcześniej. Audycja miała ugruntować wśród słuchaczy przeświadczenie o tym, że Jasna Góra faktycznie nie ucierpiała. Ukazująca się jeszcze prasa polska zakwestionowała autentyczność tego nagrania (np. „Express Poranny” nr 246: 1; „Dobry Wieczór. Kurier” nr 246: 1, oba numery z 6 września). Drugi z wymienionych dzienników pisał m.in.: „(...) przez radio wrocławskie puszczono wczoraj $\mathrm{w}$ świat zainscenizowane nagranie na styllo słuchowisko następujące. Zabrzmiało w głośnikach pytanie po niemiecku:

- Czy pan jest ojcem Motylewskim, przełożonym klasztoru Paulinów. Inny głos przetłumaczył to pytanie na język polski, po czym dały się słyszeć słowa następujące:

- Tak, jestem ojcem Motylewskim, przeorem klasztoru jasnogórskiego. W dalszym ciągu następował dialog: pytanie po niemiecku, przekład pytania na język polski i odpowiedź po polsku.

- Kiedy armia niemiecka wkroczyła do Częstochowy?

- Wczoraj, to jest w niedzielę 3 września.

- Czy ostrzeliwano klasztor?

- Klasztoru nie ostrzeliwano, ponieważ tego nie widzieliśmy i nie odczuliśmy.

- Czy obraz Matki Bożej jest uszkodzony?

- Nie, dzięki Bogu, nie jest uszkodzony".

Dalej redakcja stwierdza:

„Lakoniczność odpowiedzi, będących ścisłym powtórzeniem pytań, jest zastanawiająca. Każe przypuszczać, iż albo przeor zmuszony był mówić to, co mu dyktowano, albo mówił to kto inny. Zdania przytoczone nie brzmią zgodnie z duchem języka polskiego. (...) To rzekome sprostowanie, któremu nadano formę protokularnego niejako zeznania, zawiera prawdę zdaje się tylko w jednym, 


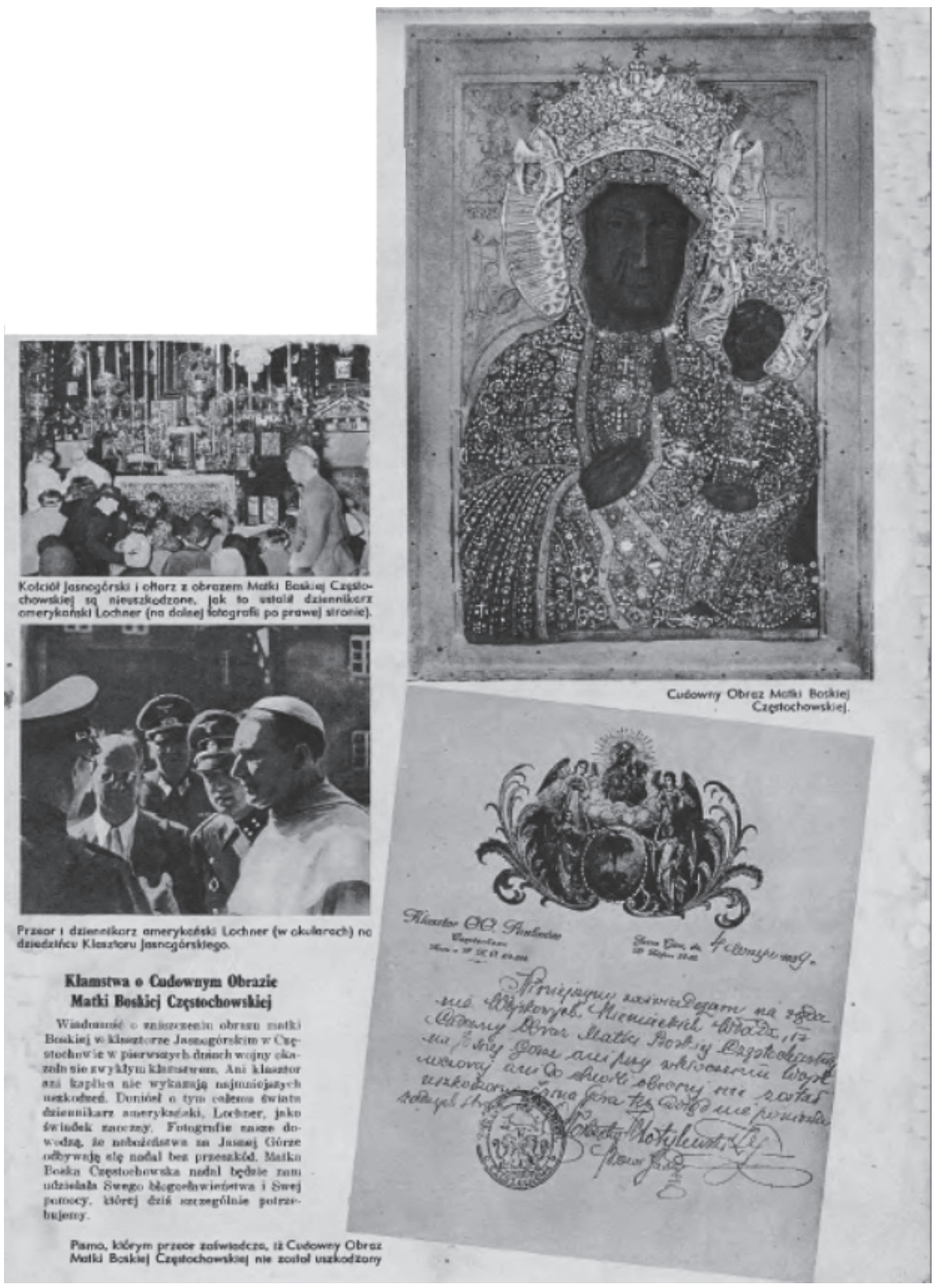

Ryc. 19. Fragment polskojęzycznego pisma niemieckiego „Ilustrowany Kurier Polski” 13 października 1939 r., nr 1, s. 2 
że obraz został na Jasnej Górze i że znajduje się pod opieką oo. Paulinów, którzy wytrwali na stanowisku, biorąc przykład $\mathrm{z}$ bohaterskiego swego przeora z czasów inwazji szwedzkiej ks. Kordeckiego. (...) Gdyby wojska niemieckie zachowały się w Częstochowie bez zarzutu, klasztor sam w innej formie mógłby powiadomić zaniepokojoną Polskę w inny sposób o losach cudownego obrazu. Tymczasem faktem jest, iż Niemcy bombardowali bezbronne miasto, klasztor Jasnogórskiej Pani, terroryzując ludność i obrzucając bombami tych mieszkańców, którzy w ucieczce z miasta szukali dla siebie ratunku. Była to masakra wołająca o pomstę do Boga tak samo, jak profanacja klasztoru jasnogórskiego".

Wykorzystując akcję propagandową związaną z odkłamywaniem nieprawdziwej informacji o zniszczeniu Jasnej Góry, Niemcy podali do wiadomości, że 18 września schwytano szpiegów angielskich, których zadaniem było zniszczenie cudownego obrazu. Było to trzech Polaków, którym bliżej nieokreślony Anglik miał nawet wypłacić po 3000 zł zaliczki i dostarczyć materiały zapalne (Pietrzykowski 1987, Zbudniewek 1991). Aresztowanie spiskowców miało być sukcesem władz niemieckich. Informację tę kolportowano zarówno na ziemiach polskich, jak też za granicą. Spotkała się ona z ostrą krytyką co światlejszych Polaków (Zbudniewek 1991). Prasa stołeczna opublikowała 20 września wypowiedź $w$ tej sprawie prezydenta Warszawy Stefana Starzyńskiego: „Naród polski znany jest ze swej religijności, znany jest z tego, że dla Matki Boskiej Częstochowskiej ma niesłychany kult jako do Królowej Korony Polskiej. Nie trzeba też światu tłumaczyć, że nie znalazłby się w Polsce człowiek, który by podniósł świętokradczą dłoń na świętość Narodu na Jasnej Górze” („Kurier Codzienny 5 Groszy” 1939 nr 260A: 2, wyd. wieczorne).

\section{7.}

Pytanie o autorstwo ,jasnogórskiej prowokacji” ciągle nurtuje badaczy. Zdaniem J. Zbudniewka (1991: 5) „rzecz (...) do dziś [jest] niewyjaśniona”. Autor ten wyraża pogląd, powtarzany też przez innych historyków (m.in. W. Bojarczuka), że plotkę o zbombardowaniu Jasnej Góry przygotowali Niemcy, a wyemitowała ją w świat $w$ dniu 2 września wieczorem niemiecka rozgłośnia radiowa we Wrocławiu. Według tej wersji celem przekazanej wiadomości miało być wywołanie uczucia wzburzenia opinii publicznej Polski i świata, ukazując przy tym w jak najgorszym świetle samych Niemców. Potem sprawę miał przejąć w swoje ręce 
osławiony minister propagandy III Rzeszy Joseph Goebbels. Z pełnym oburzeniem na niesłuszne oskarżenia zaczął je dementować, równocześnie wysyłając do Częstochowy znanego dziennikarza Lochnera. W momencie, gdy Niemcy otrzymali oświadczenia dziennikarza i przeora Motylewskiego mogli swobodnie pokazać światu, jak Polacy okłamują opinię publiczną. Równocześnie propaganda Goebbelsa ukazywała Niemców jako naród szlachetny i cywilizowany, który szczególną opiekę roztacza nad miejscami świętymi. Po publikacjach Lochnera i szerokim kolportowaniu oświadczenia przeora Motylewskiego sprawa ta w zasadzie ucichła $w$ światowych mediach. Nie powracano też do niej w przyszłości. Przyjmując, że incydent sprowokowali sami Niemcy, można stwierdzić, że w swych planach nie przewidzieli jednej rzeczy: tak gwałtownej reakcji opinii światowej, w tym również swoich aliantów. Być może właśnie ten niebywały rozgłos, jaki wzbudziła ta informacja, uratował Jasną Górę przed możliwymi późniejszymi represjami niemieckimi. Uniknęła tym sposobem tragicznego losu wielu innych polskich sanktuariów. Paulin Janusz Zbudniewek pisze, że „błogosławiona w skutkach okazała się plotka o zbombardowaniu klasztoru (...)" (1991: 86). Należy też przypuszczać, że właśnie ta historia ostatecznie zadecydowała, że Częstochowa i okolica znalazły się w granicach Generalnego Gubernatorstwa, a nie jak blisko 70\% przedwojennej diecezji włączonej do III Rzeszy. Natomiast na niemiecki rodowód tego wydarzenia może wskazywać coś innego. We wszystkich bowiem informacjach prasowych, zarówno w prasie polskiej, jak też zagranicznej, nie ma słowa o czarnym poniedziałku. Na tym musiało zależeć przede wszystkim Niemcom.

Mimo wielu przesłanek wskazujących na propagandzistów niemieckich można zadać pytanie, czy mogły być inne źródła emitujące przerażające wieści o losach klasztoru jasnogórskiego? Kto inny mógł najwięcej zyskać na szerzeniu w Polsce i w świecie tej fatalnej wiadomości? Odpowiedź na te pytania nie jest łatwa. Zastanówmy się na przykład, czy za kolportowaniem tej plotki nie mogły stać władze polskie, a konkretnie nasz kontrwywiad? Pracowało tam wielu świetnie wykształconych i obdarzonych wielką inteligencją oficerów i pracowników cywilnych. Do największych sukcesów należało rozszyfrowanie niemieckiej „Enigmy”. Bystry pracownik kontrwywiadu musiał zwrócić uwage na nagłe i raczej nieprzyjazne zainteresowanie się przed wojną Niemców Jasną Górą i cudownym obrazem Matki Bożej Częstochowskiej, a szerzej również kultem maryjnym w Polsce. Już kilka lat przed wybuchem wojny analizowano w Niemczech rolę Jasnej Góry w życiu Polaków. Stosunek do częstochowskiego 
sanktuarium stanowił jeden $z$ elementów wypracowywanej taktyki i strategii walki z narodem polskim. Generalnie nazizm zwalczał kult maryjny, uważając go za źródło polskiego poczucia godności narodowej. Po wybuchu wojny na terenach okupowanych zakazano pewnych modlitw i pieśni, niszczono obrazy z wizerunkiem Matki Bożej Częstochowskiej. Za siedlisko polskiego szowinizmu Niemcy uznawali Jasną Górę. Równocześnie jednak już wtedy zwracano wielką uwagę na to, aby oficjalna propaganda nie przynosiła szkód Jasnej Górze, a zwłaszcza cudownemu obrazowi. W lipcu 1939 r. Urząd Propagandy III Rzeszy wybił w Monachium medal z wizerunkiem Matki Bożej Częstochowskiej na awersie oraz ortem ze swastyką na rewersie. Umieszczono też tam napis, że wizerunek Czarnej Madonny „cieszy się wśród Niemców niezwykłym szacunkiem i dlatego wzięli go pod swoją szczególną opiekę" (Zbudniewek 2006: 468). W opinii historyków medal ten stanowił przejaw swoistej prowokacji. Ukazywało się szereg prac dotyczących kultu maryjnego, pisanych przez nazistowskich uczonych. W pierwszych dniach wojny opublikowano w Berlinie głośną książkę niemieckiego publicysty Petera Escha pt. Polen kreuz und Quer. Blicke hinter die Kulissen, w której scharakteryzował on range Jasnej Góry w życiu narodu polskiego i równocześnie proponował metody jej unicestwienia (Zbudniewek 1991: 66). Wydarzenia te zapewne były dyskutowane w gremiach kierowniczych naszego kontrwywiadu. Ponieważ do końca nie wiedziano, jakie plany mają Niemcy, postanowiono zaskoczyć ich, emitując w świat w dniu 2 września informację radiową o bombardowaniu Jasnej Góry. Podjęcie tej decyzji mogło wynikać z przeświadczenia, że w planach wojennych Niemiec faktycznie przewidywano zniszczenie ośrodka kultu Królowej Korony Polskiej. Większość publikowanych przez naszą prasę informacji opierała się na wiadomościach rządowej Polskiej Agencji Telegraficznej (PAT). Ukazywały się one mniej więcej przez tydzień, od 3 do 10 września. Redakcje poszczególnych gazet powtarzały nieprawdziwe przecież wieści, nie podejmując jednak choćby najmniejszej próby ich weryfikacji. Czy nie chciały, uznając materiał za prawdziwy, czy też istniał zakaz kontaktu „z terenem”? Zwraca uwagę fakt, że niektóre publikowane notatki opierały się na relacjach rzekomych „naocznych świadków”. Można odnieść wrażenie, że całość była sterowana przez stronę rządową zgodnie z zasadą, że „cel uświęca środki”. Być może nasze władze pragnęły wykorzystać tragiczne wieści z Częstochowy dla podniesienia morale społeczeństwa, a szczególnie polskich żołnierzy. Naród zaczął powoli tracić nadzieję, agresor zajmował coraz większe obszary, armia polska, która miała 
być niezwyciężona, okazała się słabym przeciwnikiem, niezdolnym do stawiania dłuższego oporu. Na terenach okupowanych rozpoczął się terror niemiecki, przejawiający się katowaniem i rozstrzeliwaniem ludności cywilnej. Wiadomość o rzekomym barbarzyństwie Niemców w stosunku do największej świętości narodowej miała zmobilizować siły, a przede wszystkim świadomość społeczną i narodową do kontynuowania dalszej walki. Stąd we wszystkich materiałach na pierwszy plan starano się wysuwać wątek patriotyczny. Przekazywane informacje konstruowano w taki sposób, aby wpływały one na podtrzymanie morale narodu, a zwłaszcza walczących żołnierzy. Stąd publikowane teksty mają często charakter patetyczny, chwytający za serce wszystkie warstwy społeczne. Na polskie źródło pochodzenia tych wiadomości może też wskazywać reakcja Niemców na wielkie wzburzenie międzynarodowej opinii. Jak pisze J. Pietrzykowski (1987: 125): „Niemcy wyłazili ze skóry, aby wiadomość tę zdementować". Podjął się tego przede wszystkim sam Goebbels, który zapewne nie spodziewał się takiego rozwoju sytuacji. Temperaturę nastrojów obniżyła relacja z wizyty na Jasnej Górze dziennikarza amerykańskiego Lochnera. Prasa światowa była pełna jego doniesień, które ostatecznie wykluczyły oskarżanie Niemców o zbombardowanie klasztoru. Jedynie ukazujące się jeszcze polskie gazety nie bardzo się tym przejęły, nadal drukując wiadomości o zniszczeniu sanktuarium. Można odnieść wrażenie, że za wszelką cenę chciały podtrzymywać w świadomości społecznej mit palącej się Jasnej Góry. Nie wydaje się, aby tak postępowali Niemcy, dla których efekty wizyty Lochnera na Jasnej Górze stanowiły przecież sukces dyplomatyczny.

Może warto dodać, że autorstwo fałszywej informacji o zniszczeniu Jasnej Góry przypisuje Polsce polskojęzyczne wydawnictwo niemieckie, jakie ukazało się w Warszawie w 1940 r²$^{2}$. Jako źródło tych wieści wskazano Polskie Radio oraz Ambasadę RP w Paryżu. W publikacji podkreślono, że dzięki wizytom w klasztorze Lochnera, a także dziennikarzy włoskich, norweskich i holenderskich i innych państw informacja „kolportowana przez polską ambasadę w Paryżu (...) okazała się wierutnym kłamstwem" (s. 22). Wątek jasnogórski kończą teksty oświadczeń Lochnera oraz przeora Motylewskiego.

2 Uwaga! Uwaga! ... Podajemy Komunikat Wojenny. Komunikaty Wojenne krajowe i zagraniczne oraz głosy prasy i radia Paryż-Londyn-Berlin-Warszawa, 1940, Wyd. Nowoczesne Sp. z o.o., Warszawa, s. 21, 22, 24, 26. „Seria Warszawska”, t. 1. 


\section{8.}

Przedstawiając sytuację Jasnej Góry w pierwszych dniach wojny, nie sposób pominąć jeszcze jednego, na poły legendarnego, wydarzenia. Dotyczy ono prób wysłania przez Niemców nad Częstochowę lotnictwa bombowego, które miało dokonać zniszczenia klasztoru i miasta.

W prasie częstochowskiej pisano 2 września, że „Niemcy zaryzykowali już kilka lotów nad naszym miastem, to jednak wszystkie samoloty zostały zmuszone do odwrotu” („Goniec Częstochowski” 1939, nr 201: 4). Krążyły też wiadomości, jakoby Hitler nakazał zburzenie klasztoru. W tym celu już 1 września z lotniska Pawelwitz (obecnie Pawłowice, część Wrocławia) wystartowały trzy eskadry samolotów bojowych, kierujące się na Częstochowę. Dwie pierwsze musiały zawrócić, ponieważ nie mogły odnaleźć celu. Trzecia eskadra nie powróciła do bazy, a niektóre samoloty musiały wylądować w szczerym polu. Dwóch pilotów z tej formacji znalazło się w szpitalach Łodzi i Lublińca. Opowiada o tym poniższa relacja.

Opowieść snuje Stanisław Biegalski, mieszkaniec Wielkopolski, który w lipcu 1939 r. przyjechał do pracy do Pawlowitz. Był zatrudniony u zaprzyjaźnionego Niemca, katolika, pracującego na lotnisku wojskowym, położonym nieopodal miejscowości. W dniu 2 września gospodarz opowiedział mu o cudzie, jakiego miała dokonać Matka Boża Częstochowska. Oto relacja przyjaciela Biegalskiego: „Wasza Madonna wczoraj i dzisiaj dokonała wielkiego cudu i nie pozwoliła zbombardować Swojej siedziby w Częstochowie. Wczoraj wysłano eskadrę samolotów celem zbombardowania Jej Kościoła. Piloci wrócili i mówili, że otrzymali złe szkice, ponieważ $w$ miejscu celu było wielkie jezioro i tam bomby rzucili. Dowództwo orzekło, że jest to sabotaż, pilotów oddano pod sąd polowy. Po południu tego dnia wysłano drugą eskadrę, i ci zawiedli, ponieważ w miejscu celu widzieli wielki bór leśny. I chociaż rzucili tam bomby, podzielili los swoich poprzednich kolegów. W dniu 2 IX 1939 r. rano wysłano trzecią eskadrę, ale z załogą składającą się z samych oficerów SS, a do tego ochotników. Nikt z tej eskadry do bazy nie wrócił. Co się z nimi stało - na razie nikt nie wie" (Hektor 1984: 59-60). Gospodarz nakazał Biegalskiemu złożyć przysięgę, że nikomu tej wiadomości nie przekaże. Następnego dnia (3 września) mocno zdenerwowany poinformował Polaka o masowych aresztowaniach osób, które rozmawiały o tych wydarzeniach. Na wszelki wypadek Biegalski opuścił Pawłowice, przenosząc się do pracy w firmie budującej drogi i mosty, której siedziba mieściła 
się we Wrocławiu-Klecina (wtedy Klettendorf). Tam wysłuchał jeszcze jednej relacji, opowiedzianej przez uczestnika tych wydarzeń, który podczas akcji utracił nogę. Dotyczyła ona historii trzeciej eskadry bombowej lecącej do Częstochowy:

„W dniu 2.09.1939 r., będąc lejtnantem lotnictwa wojskowego formacji SS, zgłosiłem się na ochotnika do eskadry, której celem było zbombardowanie kościoła z obrazem Schwarze Madonna w Częstochowie. W dniu 2.09.1939 r. zażądali ochotników dlatego, ponieważ dwie poprzednie eskadry na skutek sabotażu czy dywersji nie wykonały tego zadania. Postanowiliśmy wykonać to zadanie za wszelką cenę, gdyż taki był rozkaz naszego dowództwa SS. Zaraz po wystartowaniu, początkowo lot odbywał się normalnie. Gdzieś w połowie trasy stery nasze zaczęły działać samoczynnie i zauważyłem, że wszyscy lecą w różnych kierunkach, nie osiągając celu. Ja wylądowałem w Czechosłowacji na kartoflisku z braku benzyny. O losie kolegów nic nie wiem. Wiem, że kaleką będę do końca życia, ponieważ z Bogiem nie wolno walczyć. To moje kalectwo jest dla mnie cudem odzyskania wiary" (Hektor 1984: 60).

Relacje o tych rzekomych wydarzeniach dotarły do paulinów jeszcze podczas wojny i zostały odnotowane w księgach klasztornych. Dotyczy to również wiadomości o beznogim oficerze niemieckim. Według niektórych autorów potwierdzają one teze o interwencji Boskiej Opatrzności, która nie dopuściła nieprzyjacielskiego lotnictwa nad klasztor i miasto (Binkowski 1984: 64). Z drugiej jednak strony opowieści związane z tymi wydarzeniami nigdy nie zostały zweryfikowane i ak pisze J. Zbudniewek, ,jest mało prawdopodobne, by można je było sprawdzić w przyszłości" (1991: 56).

\section{9.}

Kończąc rozważania, należy - choć w skrócie - przypomnieć dalsze losy Jasnej Góry w latach wojny. Studia ojca J. Zbudniewka pozwalają stwierdzić, że w tamtym okresie nie przestała ona pełnić swej funkcji przewodniczki dla narodu polskiego. W 1939 r. rozdano ponad 800 tys. komunii św., w latach 1941-1943 do 420 tys., a w 1944 r. blisko 500 tys. (dla porównania w 1938 r. ponad 900 tys.). Kontynuowano wszystkie dotychczasowe nabożeństwa, nawet związane ze świętami, których obchodzenie było zakazane: Trzech Króli (6 stycznia), Królowej Korony Polskiej (3 maja), Wniebowzięcia Matki Bożej (15 sierpnia), Narodzenia Matki Bożej (8 września) i Niepokalanego Poczęcia (8 grudnia). W dni te napływ 
wiernych i pielgrzymów był szczególnie wzmożony. Ruch pielgrzymkowy nie zamarł. Mimo wielu niebezpieczeństw notowano niewielkie grupy pielgrzymów, wielu pątników przybywało też indywidualnie. Pierwsze pielgrzymki, głównie $z$ regionu częstochowskiego, pojawiły się już w marcu 1940 r. Pamiętam swoje własne pielgrzymowanie, gdy jako mały chłopiec wraz z rodziną przybywałem każdego roku z pobliskiego Olsztyna do Częstochowy. Podczas nabożeństw niedzielnych kaplica i bazylika były pełne wiernych, a wśród obecnych spory odsetek stanowiły osoby w mundurach armii niemieckiej.

Mimo oficjalnych zakazów władze Generalnego Gubernatorstwa tolerowały jasnogórskie pielgrzymki, a czynniki propagandowe nawet zachęcały do tego (m.in. polskojęzyczna prasa niemiecka). Po zajęciu przez Niemców Częstochowy „(...) na początku obwieszczenie o pełnym funkcjonowaniu sanktuarium potrzebne było dla propagandy nazistowskiej. Później tolerancja ta była nawet zalecana przez wysokich urzędników, a kiedy szala zwycięstw stawała się coraz bardziej chwiejna, zrezygnowano już z zakazów odnośnie do uroczystych nabożeństw, a nawet odbywania pielgrzymek, przed którymi oficjalnie przestrzegał gubernator Hans Frank, ale z kolei nazistowski „Kurier Częstochowski” najwyraźniej do nich zachęcał” (Zbudniewek 2006: 469). Okupant „informował w prasie i okolicznościowych ulotkach, że Jasna Góra jako duchowa stolica GG [Generalnego Gubernatorstwa] w pełni pracuje i władza zezwala na jej swobodną działalność kultową i pielgrzymkową" (Zbudniewek 1981: 348). Przez całą wojnę odbywała się Warszawska Pielgrzymka Piesza, zorganizowany charakter miały też pielgrzymki akademickie (1940-1944) z Krakowa, Warszawy, Lublina i Lwowa. Uczestniczył w nich m.in. student konspiracyjnego Uniwersytetu Jagiellońskiego Karol Wojtyła, późniejszy papież Jan Paweł II. Paulini prowadzili szeroko zakrojoną działalność społeczno-kulturalną, charytatywną, niektórzy z zakonników działali w Armii Krajowej. W miare normalnie funkcjonował Instytut Filozoficzno-Teologiczny. Mimo stacjonowania w wielu pomieszczeniach Niemców i kręcących się wokół Jasnej Góry konfidentów klasztorna furta była zawsze otwarta dla osób pilnie potrzebujących schronienia (Jackowski 2005, Zbudniewek 1991).

Licznie nawiedzali Jasną Górę również cudzoziemcy. Pierwszy wpis nosi datę 11 września 1939 r. Przybywali głównie pątnicy z państw sojuszniczych Niemiec, najwięcej z Włoch i Węgier. Bardzo sugestywny obraz swego pobytu w lutym 1942 r. zamieścił w książce Kaputt (1962) znany pisarz i dziennikarz włoski Curzio Malaparte. Swego rodzaju przychylność okazywał sanktuarium Generalny Gubernator Hans Frank, który pojawił się tutaj po raz pierwszy 25 lutego 1940 r. 


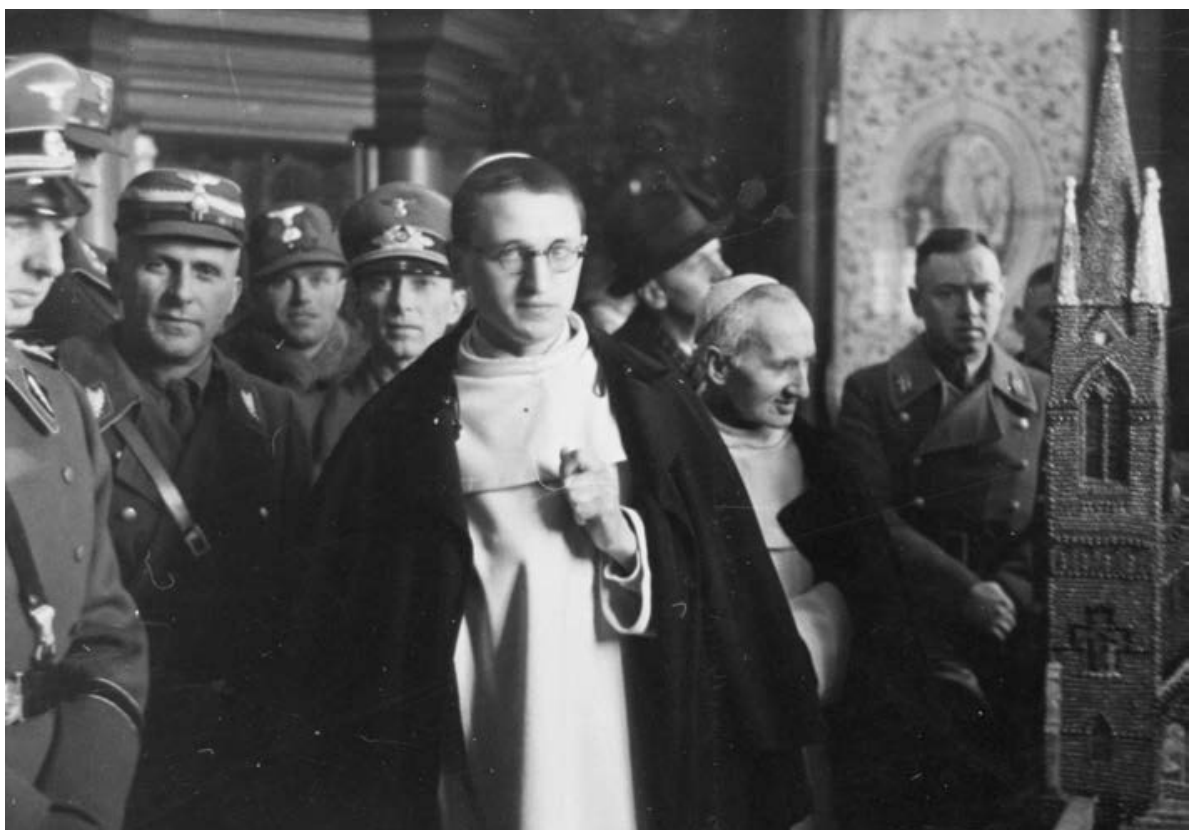

Ryc. 20. Grupa żołnierzy niemieckich w skarbcu jasnogórskim, oprowadzana przez paulinów - Walezego Strzelca (z lewej) i Mariana Paszkiewicza (NAC sygn. 2 - 4315)

Łącznie przez cały okres okupacji sanktuarium nawiedziło kilkanaście tysięcy obcokrajowców (Jackowski 2005, Zbudniewek1981, 1991).

Częstymi gośćmi na Jasnej Górze byli Niemcy (ryc. 20). Pierwszych notowano już w dniu 3 września. Organizowano dla nich specjalne nabożeństwa (np. Pasterki, Rezurekcje). W okresie od 10 września 1939 r. do 31 sierpnia 1941 r. przebywali w klasztorze niemieccy kapelani katoliccy, niestety zarażeni chorobą nazizmu (Zbudniewek 1981). W każdą niedzielę o godz. 9.30 odbywała się w bazylice msza św. dla Niemców, przez długi czas transmitowana przez radio Wrocław. W archiwaliach jasnogórskich można też odnaleźć dowody nawróceń żołnierzy i urzędników niemieckich, ale również przedstawicieli państw sprzymierzonych (m.in. Japończyków, Włochów) (Zbudniewek 1981).

Mimo wprowadzonego na ziemiach polskich terroru, masowych egzekucji, coraz liczniej tworzonych obozów koncentracyjnych, w których ginęły miliony ludzi, Niemcy w sposób niezwykle pruderyjny starali się zachować w oczach 
opinii światowej pozytywną ocenę swego postępowania wobec Jasnej Góry. Bardzo zdecydowanie dementowali wszelkie doniesienia o wrogim stosunku do klasztoru. Pragnęli stworzyć wrażenie, że sanktuarium jasnogórskie znajduje się pod ich szczególną opieką.

\section{0.}

Przedstawiona historia nie wyjaśnia, gdzie leży prawda dotycząca „kłamstwa jasnogórskiego". Jedno jest pewne: w pierwszych dniach wojny Jasna Góra była w centrum zainteresowania niemal całego świata. Żadnemu innemu pojedynczemu wydarzeniu wojennemu nie poświęcono tyle uwagi. Nawet zatopienie w dniu 3 września na Atlantyku przez niemiecką łódź podwodną angielskiego statku pasażerskiego Athenia (zginęło 118 osób) nie przyciągnęło takiej uwagi mediów. Klasztor jasnogórski był na ustach wielu przedstawicieli międzynarodowych środowisk opiniotwórczych. Spora grupa czytelników prasy światowej często po raz pierwszy dowiadywała się o istnieniu Jasnej Góry. Potem Niemcy bardzo uważali na to, aby utrwalać wizerunek klasztoru jako normalnie funkcjonującego sanktuarium. To głównie dzięki temu incydentowi Jasna Góra mogła przejść okres okupacji z niewielkimi stosunkowo stratami.

\section{Literatura}

Binkowski T., 1985, List w sprawie cudownej obrony Jasnej Góry w 1939 r., „Jasna Góra", 3 (2), s. 64.

BojarczukW., Cudowna obrona sanktuarium Matki Bożej Częstochowskiejwe wrześniu 1939 r. dakowski.pl/index.php?option=com_content\&task=view\&id=18624 ...46 (dostęp: 15 VI 2016).

Dubicki T., Majzner R., 2006, Pierwsze dni okupacji, [w:] R. Szwed (red.), Częstochowa. Dzieje miasta i klasztoru jasnogórskiego, t. 3. W czasach Polski odrodzonej i drugiej wojny światowej 1918-1945. Urząd Miasta Częstochowy, Częstochowa, s. $429-435$.

Grządzielski Z., 2006, Życie miasta pod okupacja niemiecka, [w:] R. Szwed (red.), Częstochowa. Dzieje miasta i klasztoru jasnogórskiego, t. 3. W czasach Polski odrodzonej i drugiej wojny światowej 1918-1945, Urząd Miasta Częstochowy, Częstochowa, s. 437-460. 
Hektor K., 1984, Opis cudownej obrony Jasnej Góry w dniu 1 i 2 września 1939 r., „Jasna Góra”, 2 (2), s. 59-60.

Jackowski A., 2005, Jasnogórskie pielgrzymowanie bez granic, Tyg. Katolicki „Niedziela”. Częstochowa.

Lochner L. P., 1943, What about Germany? Dodd, Mead \& Company, New York.

Malaparte C., 1962, Kaputt, „Czytelnik”, Warszawa.

Michalski P., 2014, Obraz wojny obronnej 1939 r. w świetle ówczesnej prasy polskiej. Praca doktorska, Inst. Hist. Akad. im. J. Długosza, Częstochowa. Mps, libra.bg.ajd. pl:8080/libra/doc. metadata?id=3048\&from=pubstats (dostęp:15 VI 2016).

Pietrzykowski J., 1985, Cień swastyki nad Jasna Górą. Częstochowa w okresie hitlerowskiej okupacji 1939-1945, Śląski Inst. Nauk., Katowice.

Pietrzykowski J., 1987, Jasna Góra w okresie dwóch wojen światowych. Ośrodek Dokument. i Studiów Społ., Warszawa.

Zbudniewek J., 1981, Jasna Góra w okresie okupacji hitlerowskiej, „Studia Claromontana", 1, s. 300-374.

Zbudniewek J. OSPPE, 1991, Jasna Góra w latach okupacji hitlerowskiej. Wyd. 00. Paulinów, Częstochowa.

Zbudniewek J. OSPPE, 2006, Jasna Góra w latach okupacji hitlerowskiej [w:] Szwed R. (red.), Częstochowa. Dzieje miasta i klasztoru jasnogórskiego, t. 3. W czasach Polski odrodzonej i drugiej wojny światowej 1918-1945, Urząd Miasta Częstochowy, Częstochowa, s. 461-489.

Antoni Jackowski, prof. dr hab.

Instytut Geografii i Gospodarki Przestrzennej

Uniwersytet Jagielloński w Krakowie 
